GEOGRAFIE • ROK 2012 • ČÍSLO 2 • ROČNÍK 117

BARBORA ČERNÁ, DANIEL NÝVLT, ZBYNĚK ENGEL

\title{
A BURIED GLACIOFLUVIAL CHANNEL IN THE ANDĚL COL, NORTHERN BOHEMIA: NEW EVIDENCE FOR THE MIDDLE PLEISTOCENE ICE SHEETS EXTENT IN WESTERN SUDETES
}

\begin{abstract}
ČERNÁ, B., NÝVLT, D., ENGEL, Z. (2012): A buried glaciofluvial channel in the Anděl Col, Northern Bohemia: new evidence for the Middle Pleistocene ice sheets extent in Western Sudetes. Geografie, 117, No. 2, pp. 127-151. - This study presents a new finding of glaciofluvial sediments filling a buried channel in the Anděl Col (522 m a.s.l.) in the Jizera Mts., on the Czech-Polish border. At least $550 \mathrm{~m}$ long and 55-100 m wide channel filled by glaciofluvial sediments was determined by geophysical methods in the lowermost part of the col. The base of the channel was found at a depth of 14-19 m under the present ground surface, descending from east to west draining the ice sheet front in the same direction. The channel is incised in the bedrock representing thus a Nye channel and is filled by $>13 \mathrm{~m}$ of glaciofluvial sand, gravel and mud, which is covered by 1-2 m thick colluvial deposits. The large part of the glaciofluvial package was deposited in subglacial environment reflecting the ice sheet decay events of higher release of the material from the ice sheet. The upper glaciofluvial part of sediments was deposited in front of the slowly decaying ice sheet front. No subglacial tills have been found in the col area, which is not unusual for such an exposed site. We reconstruct the maximum altitude limit of the ice sheet in the col as being at least at $~ 540 \mathrm{~m}$ and the ice thickness in the Anděl Col being few tens of metres. The Anděl Col is the highest known area in Northern Bohemia covered by an ice sheet and improves thus our knowledge about the maximum vertical extent of Middle Pleistocene ice sheets in Western Sudetes.
\end{abstract}

KEY WORDS: Nye channel - geophysical survey - subglacial and proglacial environment clast lithology - ice sheet extent - Jizera Mts. - Western Sudetes.

This research was supported by the project GAUK 92908/B-GEO/PřF and GAČR P209/10/0519.

\section{Introduction}

Northern Bohemia was repeatedly affected by continental glaciers during the Middle Pleistocene. The number of glaciations, which reached Northern Bohemia, as well as their chronology, is still the subject of discussion. However, at present three ice sheet advances reaching the Northern Bohemian territory are supported by field data and they took place during MIS 16, 12 and 6 (Nývlt et al. 2011). In spite of the uncertainty about the correct stratigraphy and chronology of ice sheet presence in Northern Bohemia, the extent and maximum altitude of the continental glaciation remains an important topic of palaeogeographic reconstructions. Based on glacial sediments and landforms Králík (1989) estimated the maximum altitude of the continental glaciation extent in Northern Bohemia at 400-500 m a.s.l. Černá (2011) inferred the 
maximum altitude of ice sheet advance on the northern slope of the Jizera Mts. for an altitude of $470-490 \mathrm{~m}( \pm 20 \mathrm{~m})$, interpreting differences in bedrock outcrop morphology and weathering characteristics.

The maximum extent of the ice sheet in Poland is defined in different detail in individual parts of Sudetes. In the Polish part of the Jizera Mts., the maximum vertical extent is delimited by a line connecting the southernmost occurrence of glacial sediments, which occur up to $420 \mathrm{~m}$ (Berg, Ahrens 1925; Kornaś 1957). However, there are indications that the maximum vertical extent of continental glaciation was higher in other parts of south-western Poland, for instance 490-500 m in Góry Kaczawskie (Traczyk 2004), $580 \mathrm{~m}$ in Góry Wałbrzyskie (Jahn 1960), $600 \mathrm{~m}$ in Góry Złote (Walczak 1968), 550-580 m in Góry Opawskie, Bardzkie and Sowie (Krzyszkowski et al. 1995). The same is true for the eastern part of Czech Sudetes, especially for the northern part of the Hrubý Jeseník Mts., where glacigenic and glaciofluvial sediments are found in the Col between Strážisko and Bílý Kámen hills at the altitude of 530-545 m (Gába 1972, Hanáček 2011). Some former authors brought evidences of a much higher ice sheet advance - up to $700 \mathrm{~m}$ in Góry Sowie (Jahn 1960, Walczak 1968). Badura and Przybylski (1998) note that some maximum altitudes of ice sheet presence have been deduced from sporadic findings of erratics, which are no longer regarded as evidential. The glacial extent, as shown by proved glacial sediments, does not exceed $550-580 \mathrm{~m}$ in the Sudetes (Badura, Przybylski 1998).

The col sites, which were crossed by ice sheets, represent key areas for reconstructing the vertical extent of the ice sheet. The Oldrrichov col $(478 \mathrm{~m})$ is the highest place currently known in Northern Bohemia being crossed over by an ice sheet (Králík 1989, Nývlt 2003). Other col sites with proved continental glacier presence lie at slightly lower altitudes: Filipov in the Šluknov Hilly land at 460 m (Nývlt 2008), Horní Col (459 m) and Jítrava Col at 424 m (Králík 1989).

The Anděl Col, which is the subject of this study, constitutes a new site documenting the vertical ice sheet extent. It is a flat col situated in eastern part of the Frýdlant Spur in a close proximity to the Czech-Polish border at an altitude of $522 \mathrm{~m}$. This site has so far been overlooked by both Czech and Polish researchers, as it is mostly covered by a mantle of colluvial deposits. Králík (1989) presented his notion that the ice sheet was present in the col using a map only, without bringing any proof. His map shows the col having been glaciated to an altitude of $\sim 540 \mathrm{~m}$. The majority of former authors has not considered the col to have been glaciated based on the regional knowledge (e.g. Sekyra 1961, Šibrava 1967) and similarly on recent maps (Berger et al. 2002, Růžička 2004), the col is shown as having lain outside the maximum extent of the ice sheet (Fig. 1). Both Czech and Polish (e.g. Walczak 1968; Szponar 1986; Badura, Przybylski 1998; Nývlt 1998) authors have offered an opinion on glaciation in the col on maps only, without any further discussion and evidences directly from the field.

Typical Nordic rocks including Baltic flint and granites from south-eastern Sweden were found on the surface of the col, including small clasts and blocks up to $0.5 \mathrm{~m}$ large. These findings are not regarded indicative for glaciation, as they are very probably not in situ and may have been relocated to improve forest roads. Tíma (pers. com., 2007) was the first to call attention to the occurrence of Nordic rock under the surface when he discovered and photographed 


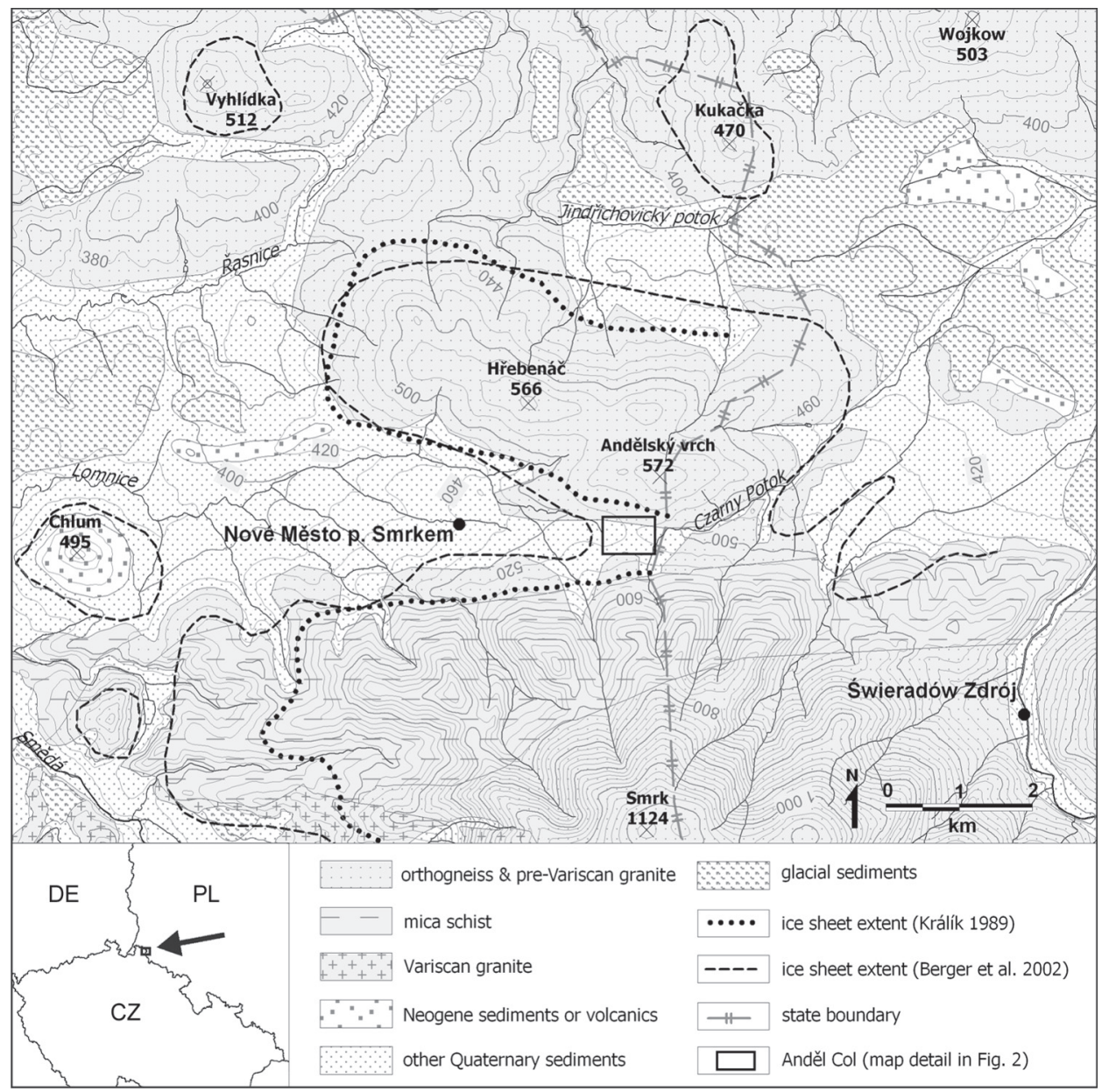

Fig. 1 - Sketch geological map of the surrounding of the Anděl Col with the maximum ice sheet extent according to former authors and location of the study area.

flints in the roots of trees toppled by the wind. This information prompted the research into the Anděl Col. The aim of the research was to show whether glacial sediments were present and to determine their properties, genesis, depth and position. To reveal this geophysical and sedimentological methods have been employed. Based on these findings, it is our objective to reconstruct further palaeoglaciological details, such as the glacial advance direction or the glaciofluvial flow direction at the site and, eventually, to derive vertical ice sheet extent for the surrounding area.

\section{Study site}

The Anděl Col is situated in Northern Bohemia in the Frýdlant Spur, between Smrk (1124 m) and Anděl Hill (572 m; Fig. 1). Since the col has no name 
on maps, we refer to it here as "the Anděl Col". The landscape slopes down to the Lomnice Valley towards the west and to Granicznik and Czarny Potok Valley to the east. The col has a large flat part measuring about $200 \times 80 \mathrm{~m}$ with gentle adjacent slopes $\left(<5^{\circ}\right)$.

The study area is situated in the Krkonoše-Jizera Region and the bedrock belongs to the Early Paleozoic Jizera Metamorphic Complex (JMC) according to Kozdrój et al. (2001). The Anděl Col and associated slopes to the north are composed of augen-type orthogneiss. Further north from the col the bedrock is composed of biotite granites to metagranitoids (Chaloupský 1990, Kozdrój et al. 2001, see also Fig. 1). South of the col lies a belt of chlorite-muscovite schists with lenses of amphibolite (Chaloupský 1990, Kozdrój et al. 2001). The bedrock in the col and its surroundings is covered by Quaternary colluvial deposits according to the former geological map (Chaloupský 1990). The nearest mapped glacial sediments are situated in Poland, $\sim 5 \mathrm{~km}$ East and Northeast from the col. These are tills and glaciofluvial sediments, both at a maximum altitude of $420 \mathrm{~m}$ (Kornaś 1957). In Czechia, glacial sediments occur $\sim 5.5 \mathrm{~km}$ to the west of the col (Chaloupský 1990). These sediments were described by Králík (1989) as glaciofluvial deposits with an altitude not exceeding $420 \mathrm{~m}$.
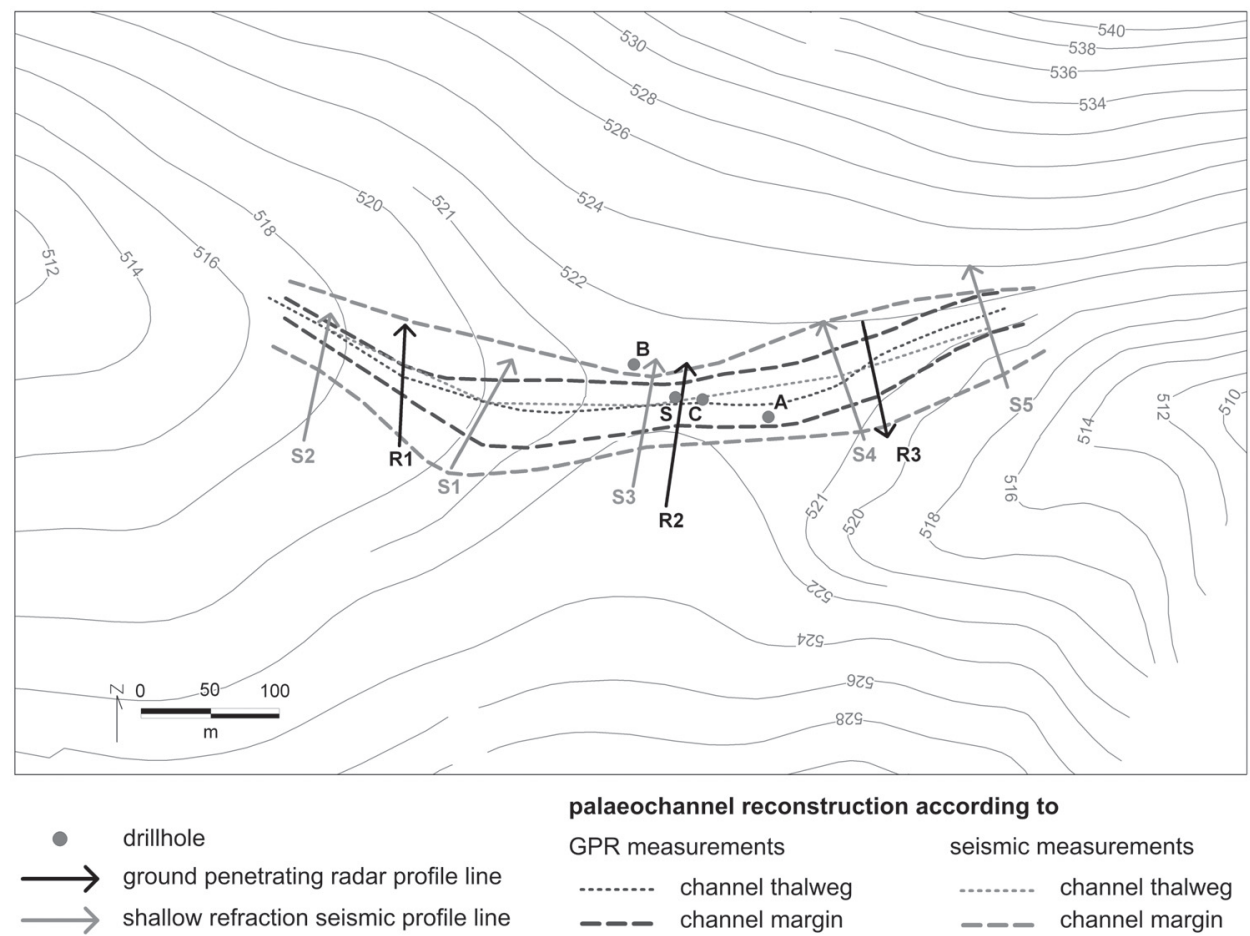

palaeochannel reconstruction according to

GPR measurements

......... channel thalweg

- channel margin seismic measurements

channel thalweg channel margin

Fig. 2 - Contour map of the Anděl Col with locations of drillholes A, B, C and S, ground penetrating radar profile lines $\mathrm{R} 1, \mathrm{R} 2$ and $\mathrm{R} 3$, shallow refraction seismic profile lines $\mathrm{S} 1$, S2, S3, S4 and S5, reconstructed thalweg and margin of the palaeochannel according to both geophysical methods used. Arrows mark the direction of GPR and seismic profiles shown in Figs. 9 and 10. 


\section{Methods}

\subsection{Geophysical methods}

Ground penetrating radar (GPR) is a technique, which detects subsurface boundaries via the transmission and reception of high-frequency electromagnetic energy. The equipment used consisted of a RAMAC/GPR CUII unit and a $50 \mathrm{MHz}$ unshielded antenna (RAMAC RTA), which was found to gain the best depth penetration and resolution. The antenna had a constant separation of $4 \mathrm{~m}$ and was pulled manually at a constant speed. The movement was measured in time, with a trace interval of $0.1 \mathrm{~s}$. The location of profiles was registered using GPS (Fig. 2). In total, 37 GPR profile lines with a total length of $4.98 \mathrm{~m}$ were measured in the col. The data were processed and plotted using RAMAC GroundVision software. Two filters were applied: DC removal and time-varying gain. The ground velocity for time to depth conversion was set to $100 \mathrm{~m} / \mathrm{\mu s}$.

Shallow seismic refraction measurements enable the bedrock surface to be mapped and also allow for the determination of P-wave velocities in the bedrock. Measurement was conducted along five profile lines, each $92 \mathrm{~m}$ long. The position of the profile lines was selected according to the GPR results to cross the deepest part of sedimentary structures. For each profile 24 geophones (SM4 $10 \mathrm{~Hz}$ ) were placed in an array with a spacing of $4 \mathrm{~m}$. Cumulative 6-kg hammer shots were used as a seismic source. Seven shot-points were used for each line, five situated inside the array (middle, quarters and both ends) and two outside the array at a distance of $20-30 \mathrm{~m}$ from both ends. A 24-channel Seismograph ABEM Mark6 was used to acquire the seismic data. The data were then processed and interpreted using REFLEXW software 5.0.

\subsection{Sediment drilling}

Three cores were drilled using a percussion gouges (Eijkelkamp), with a diameter of 100, 75 and $50 \mathrm{~mm}$. Two cores $(\mathrm{A}, \mathrm{C})$ were situated inside the channel mapped by geophysical methods and one (B) outside, as shown on Figure 2. The maximum drilling depth was $4.28,5.10$ and $2.35 \mathrm{~m}$ respectively, as a greater depth could not be reached using the hand-drilling equipment. The percussion gouges allowed the sampling of undisturbed sediments. One core (S) located in the deepest part of the channel was drilled using a truck mounted core sampler with a diameter of $100 \mathrm{~mm}$. The maximum depth reached was $16 \mathrm{~m}$. This type of drilling enabled sampling of semi-disturbed sediment.

\subsection{Sedimentological analyses}

Grain-size analyses were performed in 51 samples from all cores. The total of 43 samples was analysed by dry sieving. A set of sieves at whole phi-unit intervals from $-5 \Phi(32 \mathrm{~mm})$ up to $4 \Phi(0.063 \mathrm{~mm})$ was used. If more than $5 \%$ of sample passed the $0.063 \mathrm{~mm}$ sieve, the 0.050 and $0.040 \mathrm{~mm}$ sieves were added. Every sample was sieved in a sieve shaker for 10-20 min. and then 
weighed on a scale with $0.1 \mathrm{~g}$ accuracy. Eight samples from cores A and C with high silt and clay content, which could not be effectively analysed by dry sieving, were processed by hydrometer analysis following the method proposed by Head (1984). The size-distribution curve was constructed for each sample and percentiles read off. Then the graphic mean $\left(M_{z}\right)$, inclusive graphic standard deviation $(\sigma)$, inclusive graphic skewness $\left(S k_{I}\right)$ and graphic kurtosis $\left(K_{G}\right)$ were calculated according to Folk and Ward (1957). Each sample was classified according to sand/silt ratio and gravel share (Folk 1954).

Gravel samples were chosen for clast petrological analyses. In sum, 16 samples were processed from cores A, C and S. The size fractions used were 4-8 $\mathrm{mm}$ and 8-16 $\mathrm{mm}$, although the latter did not provide enough clasts in some samples to guarantee statistical confidence. 12 basic petrological classes were identified and categorized into four plus one (indetermined clasts) provenance groups: local, near, nordic and undefined, represented by quartz since its provenance cannot be unequivocally identified. Small shares of indetermined clasts could also have not been categorized from the provenance point of view.

Clast shape and roundness analysis was performed on eight samples from core S. In each sample 50 quartz clasts from $4-8 \mathrm{~mm}$ fraction were measured. Clasts were measured using a slide calliper, following the instructions of Gale and Hoare (1991). The data were plotted in ternary diagrams as proposed by Sneed and Folk (1958), using the software of Graham and Midgley (2000). Clast roundness was classified in six-classes after Powers (1953) and plotted in histograms. To display both shape and roundness, the $\mathrm{C}_{40} / \mathrm{RA}$ diagram was used (Benn, Ballantyne 1994).

Heavy minerals were studied in order to examine material sources, which do not originate from local bedrock. Eight samples from cores B and C were selected for this analysis. Six samples were chosen from core $\mathrm{C}$ and two from core B, which was situated outside the channel, so that those samples could serve for comparison of in-channel and off-channel material. The fraction between 0.04 and $0.5 \mathrm{~mm}$ was sieved. The samples were processed in laboratory of the Czech Geological Survey in Prague. Heavy minerals were separated in a $2.95 \mathrm{~g} . \mathrm{cm}^{-3}$ dense liquid and analysed under a binocular and polarization microscope. Shares of each mineral were calculated for individual samples.

\section{Results}

\subsection{Channel infill}

Sedimentary succession in cores A, C and S comprises alternating layers of sand, gravel and mud (Fig. 3, Tab. 1). In the lower part of the channel infill (below $6 \mathrm{~m}$ of depth) gravel deposits prevail, alternating with some muddy and sandy layers (see Fig. 3). In the uppermost $6 \mathrm{~m}$ of the channel infill sandy layers predominate, sporadically alternating with layers of mud or gravel. Outside the channel (core B) only sandy and gravel sediments were found (Fig. 3). No core, including the $16 \mathrm{~m}$ deep core $\mathrm{S}$, was deep enough to reach the solid bedrock.

In core $\mathrm{B}$, drilled outside of the channel, the depth reached was $2.35 \mathrm{~m}$, where a weathered orthogneiss stone was drilled. Coarse gravel with common angular orthogneiss clasts up to $30 \mathrm{~mm}$ long continue up to $1.65 \mathrm{~m}$, where the gravel 

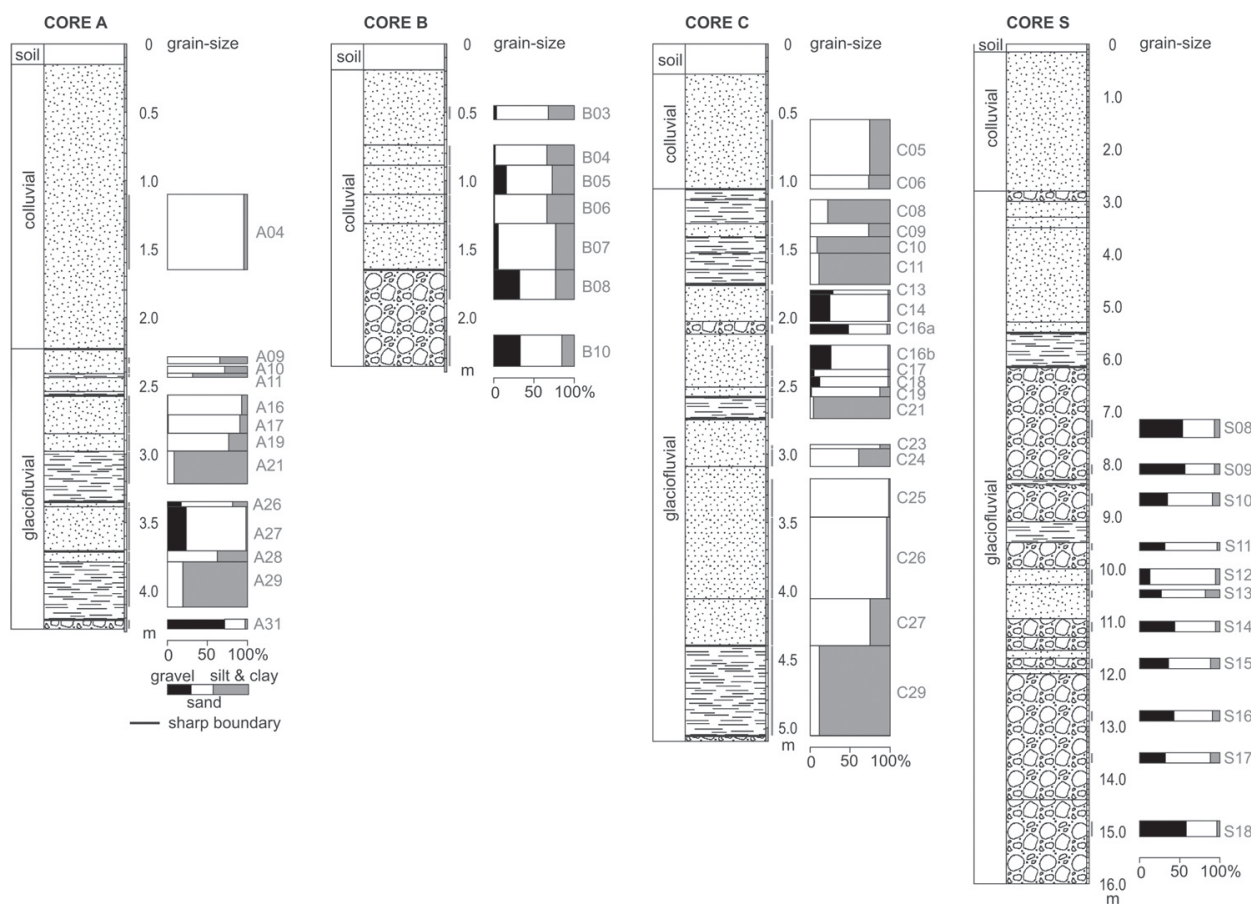

Fig. 3 - Lithological logs of cores A, B, C and S including interpretation of depositional environment and grain-size distribution of samples indicated. See Fig. 2 for core locations and Table 1 for grain-size parameters of the samples. Note different scale for core S.

changes to a massive sand, which continues up to the surface being topped by $0.2 \mathrm{~m}$ of humic a-horizon (Fig. 3).

The succession in core $\mathrm{C}$ started at depth of $5.1 \mathrm{~m}$, where coarse gravel prevented deeper drilling. Above the sharp boundary at $5.06 \mathrm{~m}$ laminated mud continues up to $4.40 \mathrm{~m}$. From 4.40 to $2.75 \mathrm{~m}$ thinly laminated to bedded sand with laminae/beds from $1 \mathrm{~mm}$ up to several tens of mm thick predominate. From 2.75 to 2.58 a distinct layer of thinly laminated mud is present. Gravelly sand to sandy gravel continues above the sharp erosional boundary at $2.58 \mathrm{~m}$, the cycle with coarsening upwards to $\sim 2.10 \mathrm{~m}$ and later with fining upwards continues up to $1.78 \mathrm{~m}$. After a sharp boundary at this depth thinly laminated to horizontally bedded mud dominates, with 1-30 mm thick laminae to beds and some silty sand beds, such as those found at a depth of 1.31-1.41 m, continues up to $1.05 \mathrm{~m}$. The uppermost part of the sedimentary succession is made of massive sand, where darkening upwards may be seen, topped by $0.2 \mathrm{~m}$ of humic a-horizon (Fig. 3).

In core $\mathrm{A}$, where the maximum depth reached was $4.30 \mathrm{~m}$, the lowermost $100 \mathrm{~mm}$ were composed of gravel. Above the sharp boundary at $4.20 \mathrm{~m}$ fine mud with 2-5 mm thick lamination continues up to $3.70 \mathrm{~m}$, where coarsening upwards sand with a high gravel proportion follows another sharp boundary and continues up to $3.37 \mathrm{~m}$. There is another sharp boundary, at which a layer of mud begins and coarsens up to sand continuing up to $2.58 \mathrm{~m}$. Above the sharp contact at $2.58 \mathrm{~m}$ alternating thinly laminated mud and sand layers with laminae $1-10 \mathrm{~mm}$ thick are present. They terminate at $2.22 \mathrm{~m}$, where 
Tab. 1 - Grain size characteristics and sediment classification of samples from cores A, B, C and S. $M_{z}=$ graphic mean, $\sigma=$ inclusive graphic standard deviation, $S k_{I}=$ inclusive graphic skewness, $K_{G}=$ graphic kurtosis.

\begin{tabular}{|c|c|c|c|c|c|c|}
\hline $\begin{array}{l}\text { Sample } \\
\text { name }\end{array}$ & $\begin{array}{l}\text { Depth } \\
\text { (m) }\end{array}$ & $\begin{array}{l}\text { Classification } \\
\text { (Folk 1954) }\end{array}$ & $\begin{array}{l}M_{z} \\
(\Phi)\end{array}$ & $\begin{array}{c}\sigma \\
(\Phi)\end{array}$ & $\begin{array}{l}\mathrm{Sk}_{\mathrm{I}} \\
(\Phi)\end{array}$ & $\begin{array}{l}\mathrm{K}_{\mathrm{G}} \\
(\Phi)\end{array}$ \\
\hline A04 & $1.10-1.65$ & sand & 2.55 & 0.65 & 0.10 & 1.43 \\
\hline A09 & $2.29-2.34$ & muddy sand & 3.60 & 1.03 & 0.13 & 1.16 \\
\hline A10 & $2.36-2.41$ & muddy sand & 3.44 & 1.04 & -0.03 & 1.16 \\
\hline A11 & $2.41-2.44$ & sandy mud & 4.68 & 1.52 & 0.29 & 1.33 \\
\hline A16 & $2.57-2.71$ & sand & 2.28 & 1.05 & 0.00 & 1.19 \\
\hline A17 & $2.71-2.85$ & sand & 2.44 & 1.14 & -0.03 & 1.45 \\
\hline A19 & $2.85-2.98$ & muddy sand & 3.36 & 0.89 & 0.15 & 0.96 \\
\hline $\mathrm{A} 21$ & $2.98-3.22$ & mud & 5.55 & 1.69 & 0.55 & 1.83 \\
\hline A26 & $3.36-3.37$ & gravelly muddy sand & 1.81 & 2.54 & -0.40 & 1.19 \\
\hline $\mathrm{A} 27$ & $3.37-3.71$ & gravelly sand & 0.34 & 1.77 & -0.35 & 0.96 \\
\hline A28 & $3.71-3.79$ & muddy sand & 3.67 & 1.03 & 0.09 & 1.21 \\
\hline A29 & $3.80-4.12$ & sandy mud & 5.08 & 1.66 & 0.55 & 1.47 \\
\hline A31 & $4.22-4.28$ & sandy gravel & -2.07 & 2.59 & 0.47 & 0.93 \\
\hline B03 & $0.45-0.55$ & slightly gravelly muddy sand & 3.33 & 1.50 & -0.45 & 1.04 \\
\hline B04 & $0.74-0.89$ & muddy sand & 3.48 & 1.19 & -0.10 & 1.19 \\
\hline B05 & $0.90-1.10$ & gravelly muddy sand & 2.04 & 2.56 & -0.31 & 1.73 \\
\hline B06 & $1.10-1.31$ & muddy sand & 3.32 & 1.23 & -0.21 & 0.87 \\
\hline B07 & $1.31-1.65$ & gravelly muddy sand & 2.73 & 1.69 & -0.25 & 1.15 \\
\hline B08 & $1.65-1.87$ & muddy sandy gravel & 1.02 & 3.06 & -0.15 & 0.59 \\
\hline B10 & $2.13-2.36$ & muddy sandy gravel & 0.75 & 3.08 & -0.15 & 0.70 \\
\hline $\mathrm{C} 05$ & $0.55-0.96$ & muddy sand & 3.55 & 1.02 & -0.27 & 0.98 \\
\hline $\mathrm{C} 06$ & $0.96-1.06$ & muddy sand & 3.33 & 1.10 & 0.15 & 1.07 \\
\hline $\mathrm{C} 08$ & $1.14-1.31$ & sandy mud & 4.65 & 1.31 & 0.53 & 3.55 \\
\hline $\mathrm{C} 09$ & $1.31-1.41$ & muddy sand & 3.57 & 0.77 & 0.02 & 0.99 \\
\hline $\mathrm{C} 10$ & $1.41-1.53$ & mud & 4.88 & 1.23 & 0.72 & 2.72 \\
\hline C11 & $1.53-1.65$ & sandy mud & 6.20 & 2.06 & 0.20 & 0.94 \\
\hline $\mathrm{C} 13$ & $1.80-1.83$ & gravelly sand & 0.07 & 1.70 & 0.13 & 0.90 \\
\hline C14 & $1.83-2.03$ & gravelly sand & 0.37 & 1.90 & -0.39 & 0.93 \\
\hline $\mathrm{C} 16 \mathrm{a}$ & $2.05-2.12$ & sandy gravel & -1.03 & 2.54 & -0.05 & 0.69 \\
\hline $\mathrm{C} 16 \mathrm{~b}$ & $2.20-2.38$ & gravelly sand & 0.56 & 2.01 & -0.37 & 0.84 \\
\hline $\mathrm{C} 17$ & $2.38-2.43$ & gravelly sand & 1.94 & 1.15 & -0.21 & 1.47 \\
\hline C18 & $2.43-2.50$ & gravelly sand & 1.22 & 1.66 & -0.28 & 1.13 \\
\hline C19 & $2.51-2.58$ & muddy sand & 2.98 & 0.92 & 0.22 & 1.12 \\
\hline $\mathrm{C} 21$ & $2.58-2.65$ & mud & 5.40 & 1.42 & 0.51 & 1.28 \\
\hline $\mathrm{C} 23$ & $2.93-2.96$ & muddy sand & 3.15 & 0.73 & 0.10 & 0.88 \\
\hline $\mathrm{C} 24$ & $2.96-3.09$ & muddy sand & 3.86 & 0.76 & 0.23 & 1.15 \\
\hline $\mathrm{C} 25$ & $3.18-3.46$ & sand & 2.08 & 0.62 & 0.03 & 0.83 \\
\hline $\mathrm{C} 26$ & $3.46-4.06$ & sand & 2.69 & 0.59 & 0.27 & 1.22 \\
\hline $\mathrm{C} 27$ & $4.06-4.38$ & muddy sand & 3.52 & 0.76 & 0.03 & 1.05 \\
\hline $\mathrm{C} 29$ & $4.40-5.06$ & sandy mud & 5.25 & 1.55 & 0.56 & 1.47 \\
\hline S08 & $7.15-7.50$ & muddy sandy gravel & -0.91 & 3.10 & 0.18 & 0.79 \\
\hline S09 & $8.00-8.20$ & muddy sandy gravel & -1.07 & 3.24 & 0.21 & 0.73 \\
\hline S10 & $8.55-8.80$ & muddy sandy gravel & 0.16 & 2.68 & 0.11 & 0.91 \\
\hline S11 & $9.50-9.65$ & sandy gravel & 0.15 & 2.08 & 0.09 & 0.94 \\
\hline S12 & $10.00-10.30$ & gravelly sand & 1.00 & 1.68 & -0.16 & 1.60 \\
\hline S13 & $10.40-10.55$ & gravelly muddy sand & 1.25 & 2.92 & -0.41 & 0.68 \\
\hline S14 & $11.00-11.20$ & sandy gravel & -0.46 & 2.26 & 0.17 & 1.05 \\
\hline S15 & $11.70-11.90$ & muddy sandy gravel & 0.24 & 2.99 & 0.05 & 0.80 \\
\hline S16 & $12.70-12.90$ & muddy sandy gravel & -0.11 & 2.91 & 0.16 & 0.90 \\
\hline S17 & $13.50-13.70$ & muddy sandy gravel & 0.41 & 2.89 & -0.02 & 0.94 \\
\hline S18 & $14.80-15.10$ & sandy gravel & -1.13 & 2.37 & 0.21 & 1.13 \\
\hline
\end{tabular}


they are sharply replaced by massive sand, which changes from light to dark yellow towards the surface, where $0.15 \mathrm{~m}$ of humic a-horizon is present (Fig. 3).

In core $\mathrm{S}$, the maximum drilled depth was $16.00 \mathrm{~m}$. Most of the sedimentary succession is composed of gravel, which predominates in the lower part, up to $6.15 \mathrm{~m}$. Further up, gravel is replaced by a few metres of laminated layers of mud and sand. Above the sharp boundary at $6.15 \mathrm{~m}$ a muddy layer with laminae $2-10 \mathrm{~mm}$ thick continues up to $5.50 \mathrm{~m}$, where another sharp boundary is present, above which sand alternating sporadically with layers of mud or gravel continues up to the surface with just $0.15 \mathrm{~m}$ of humic a-horizon (Fig. 3). The upper $5 \mathrm{~m}$ of sediments in core $\mathrm{S}$ may be well correlated with sediments in the core $\mathrm{C}$ and the latter was used for interpretations of the uppermost part of the succession due to a preferable drilling method.

Sedimentary characteristics in alternating layers differ markedly. All available grain size statistical parameters and classifications are given in Table 1. The grain size distribution of the material from cores A, B, C and S together with interpreted depositional environment is shown on Figure 3.

The principal statistical parameters of grain-size distribution for individual glaciofluvial and colluvial samples from cores B, C and S are plotted in Figure 4 to show differences of individual glaciofluvial and colluvial facies. Glaciofluvial sediments ranges from fine silt to gravel. Best sorted is always medium to fine sand, which is usually moderately sorted. Glaciofluvial fines with the graphic mean in the range of fine to coarse silt are poorly sorted and mostly very negatively skewed. Coarse-grained glaciofluvial facies represented by gravely sand to gravel are poorly to very poorly sorted and mostly negatively skewed, only coarse sandy sediments are positively to very positively skewed. On the other hand, the mostly sandy colluvial sediments are always sorted worse than corresponding glaciofluvial facies and are typically positively to very positively skewed (Fig. 4), which shows on the admixture of fines comparing to the glaciofluvial material.

Clast petrological analyses were studied from the viewpoint of petrological and provenance composition of gravel material. The highest proportions (usually $70-85 \%$ ) are typical for local petrotypes (Tab. 2, Fig. 5), which consist of JMC orthogneiss, metagranitoid and mica schist. They are present in variable proportions, however the most common are clasts of metagranitoid, followed by orthogneiss, with mica schist clasts being less common (Tab. 2). Quartz is regarded as undetermined according to its provenance, as it may originate from different local, near or Nordic rocks. The share of quartz is typically $10-25 \%$, with some outliers up to $43 \%$. Near and Nordic rocks are present in nearly all samples examined; they usually make up less than $4-5 \%$ of all clasts. Neogene volcanic rocks, Cretaceous sandstones from Poland, Jizera granite, different quartzites and one palaeorhyolite (Sudeten porphyry) from the North-Sudetic Trough (with outcrops south of Lwówek Ślaski) or the area surrounding Walbrzych represent near rocks which must have been transported towards the col area by an ice sheet either directly from their outcrops or more probably from older fluvial deposits. Nordic rocks consist of crystalline rocks (mostly granites from Småland, rapakivi granites mostly from Åland islands, porphyries and granitoids from Dalarna), Fennoscandian Jotnian sandstones, Baltic flints and cherts (Tab. 2). The vertical trend in shares of individual provenance groups in core $\mathrm{S}$ is given in Figure 6. 

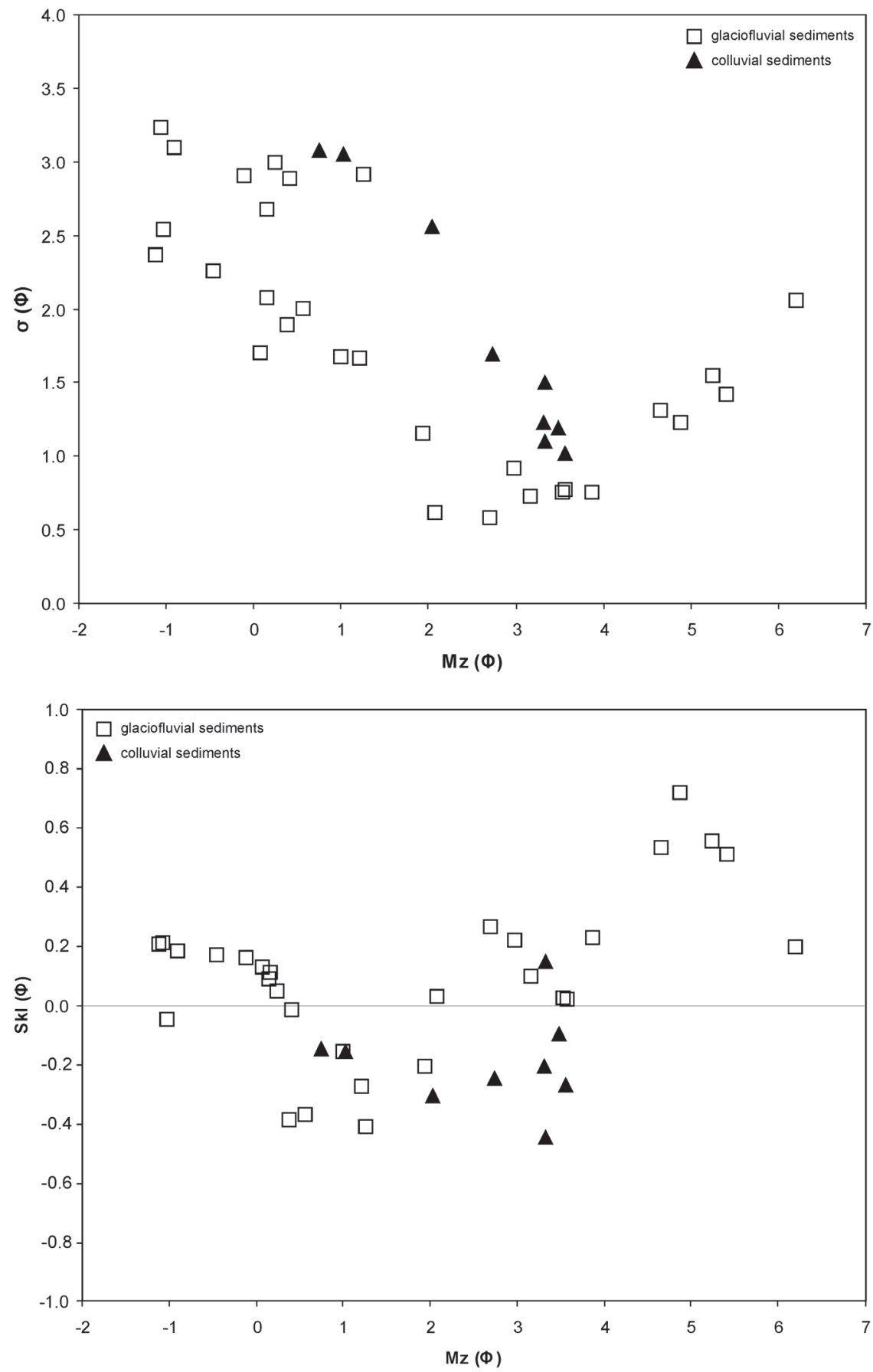

Fig. 4 - Covariant plots of graphic mean $\left(M_{z}\right)$ and inclusive graphic standard deviation $(\sigma)$, and graphic mean $\left(M_{z}\right)$ and inclusive graphic skewness $\left(S k_{I}\right)$ for glaciofluvial and colluvial sediments from cores B, C and $\mathrm{S}$. 


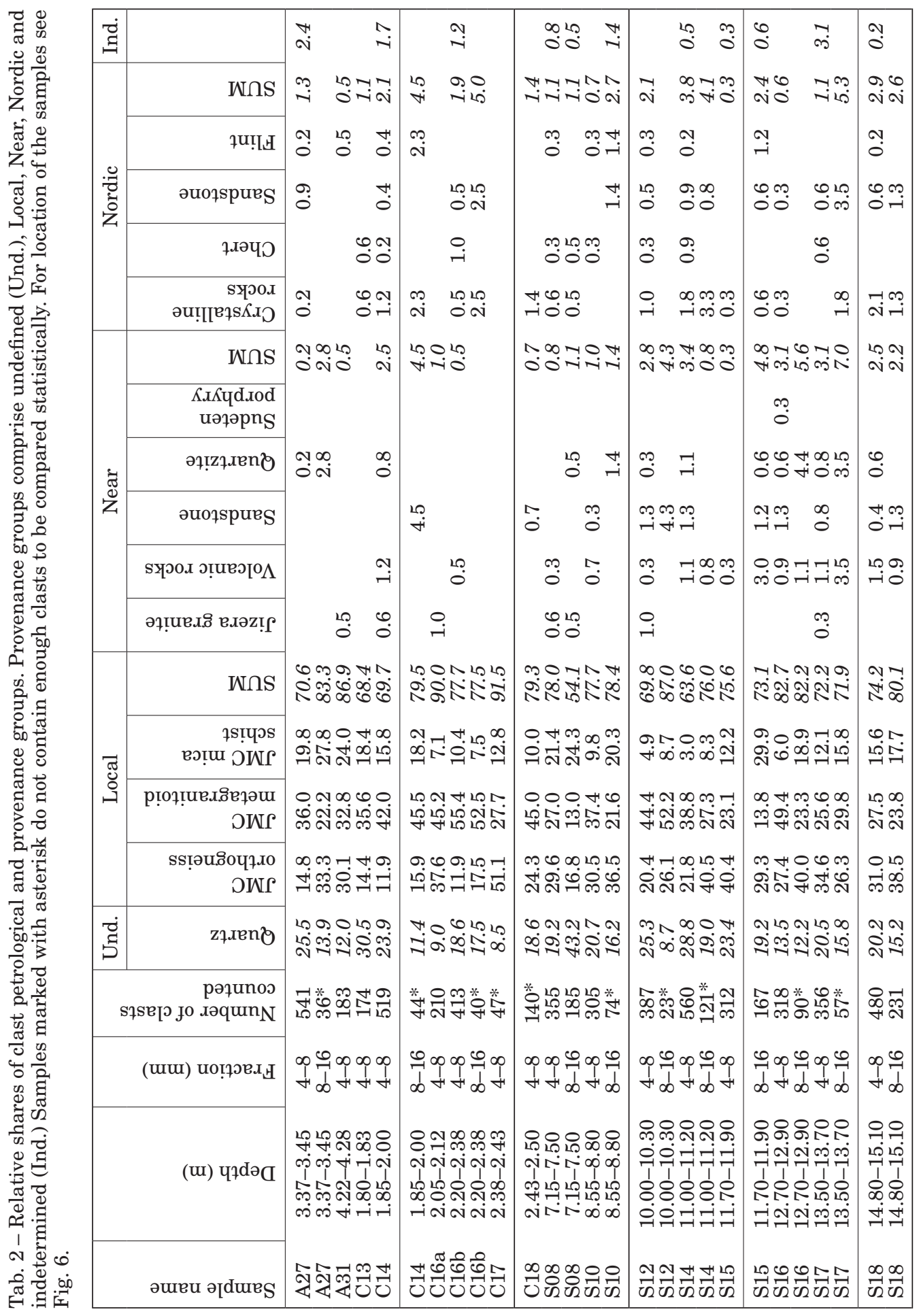



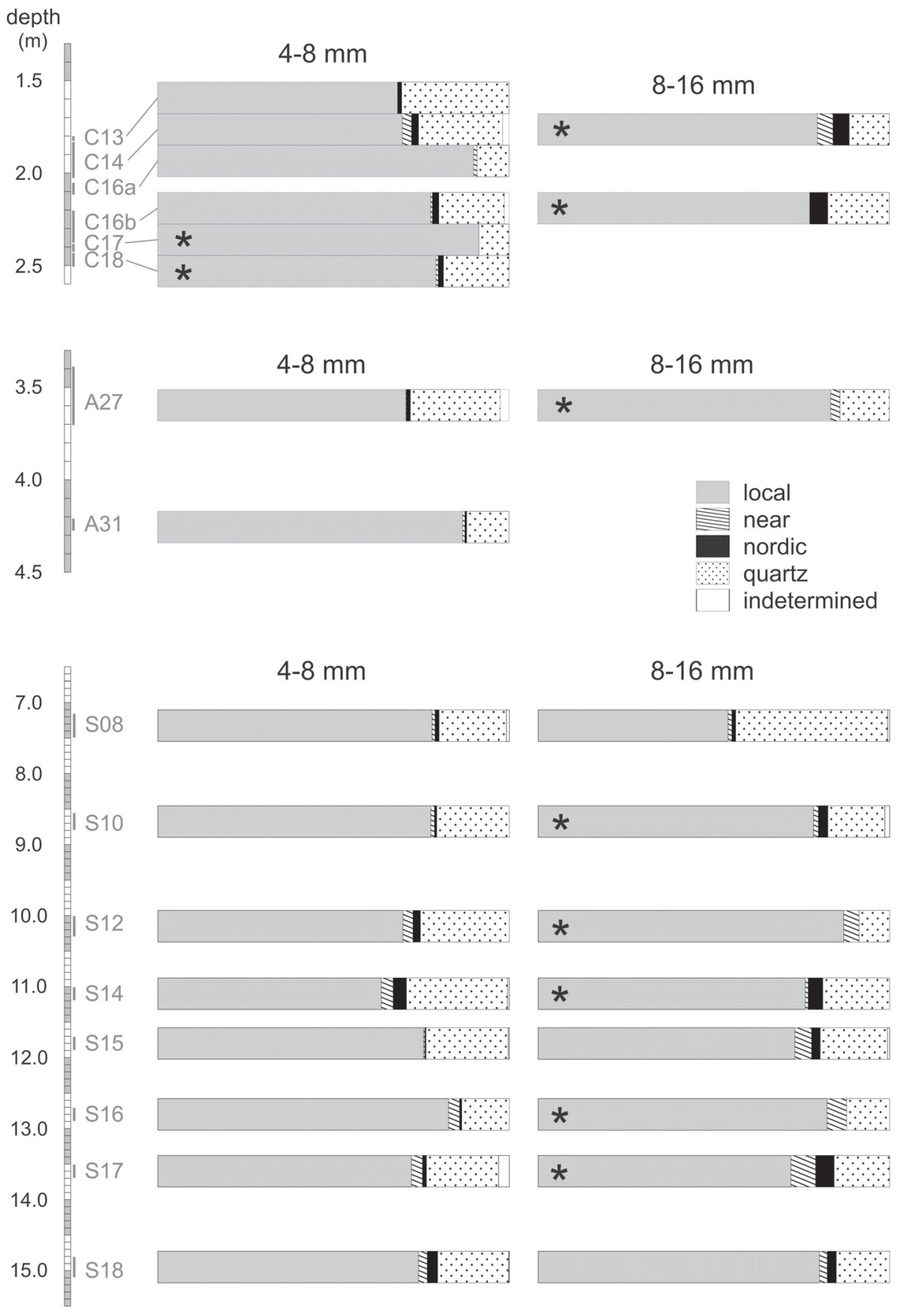

Fig. 5 - Vertical trends of gravel clast provenance groups for glaciofluvial sediments from cores C, A and S. Samples marked with asterisk do not contain enough clasts to be compared statistically. 
Fig. 6 - Vertical changes of gravel clast provenance groups from the fraction $4-8 \mathrm{~mm}$ of the core $\mathrm{S}$.

Ternary diagrams (Fig. 7) display the quartz clast shapes of sediments from core $\mathrm{S}$. The shape is variable, but bladed, compact-bladed and compact-elongate clasts predominate (Sneed, Folk 1958). The samples' $\mathrm{C}_{40}$ index varies between 14 and $28 \%$. Clast roundness of quartz clast from core $\mathrm{S}$ is shown in histograms in Figure 8. In most samples, subangular clasts dominate, however sample S18 is composed of more angular clasts and in sample S10 subrounded clasts prevail. The share of RA clasts (very angular and angular clasts) varies between 14 and $48 \%$.

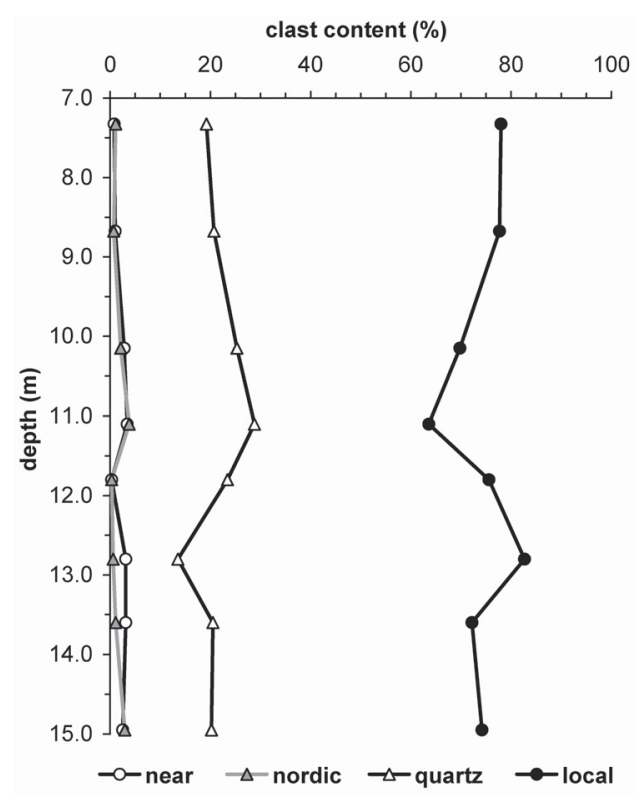

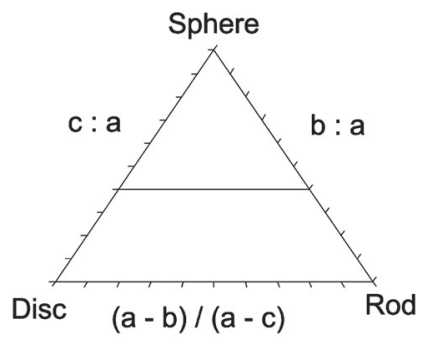
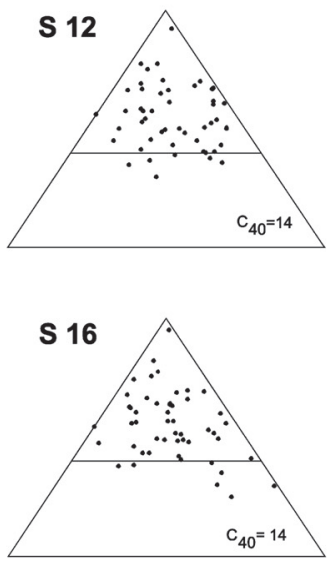
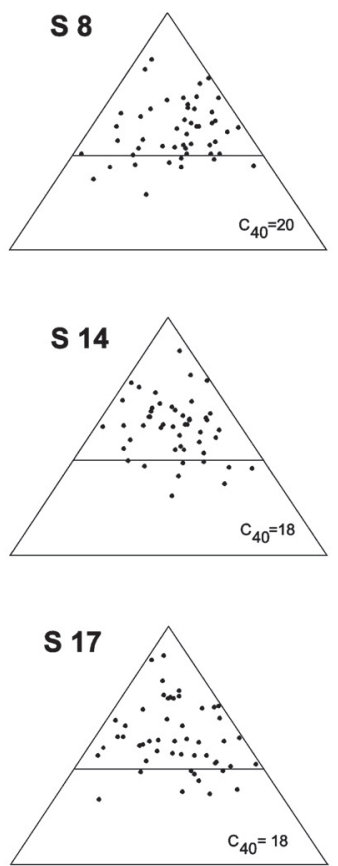
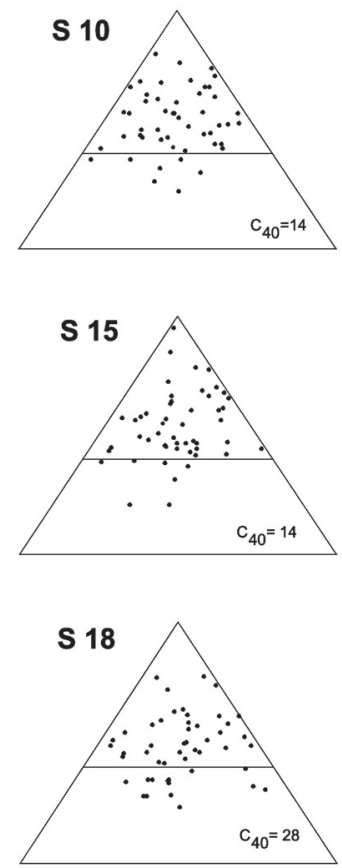

Fig. 7 - Ternary diagrams showing quartz gravel clasts shape of the samples from the core $\mathrm{S}$, together with the $\mathrm{C}_{40}$ values. For location of the samples see Fig. 6 and Tab. 1. 
Tab. 3 - Relative shares of heavy minerals for the samples derived from cores B and C. For location of the samples see Fig. 3.

\begin{tabular}{|c|c|c|c|c|c|c|c|c|c|c|c|c|c|c|}
\hline 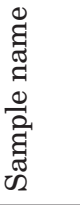 & 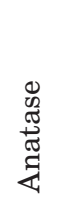 & 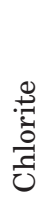 & 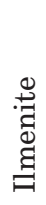 & 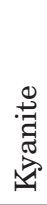 & 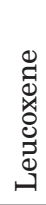 & 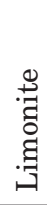 & 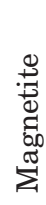 & 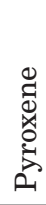 & $\underset{\text { 营 }}{\stackrel{0}{7}}$ & 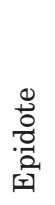 & 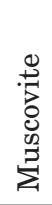 & $\begin{array}{l}\stackrel{0}{0} \\
\text { 营 } \\
.0\end{array}$ & 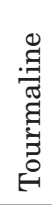 & 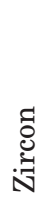 \\
\hline B06 & & 5 & & & & 1 & & & 60 & & & & 30 & 4 \\
\hline B07 & & 10 & & & & 5 & & & 50 & & & & 30 & 5 \\
\hline C09 & $<1$ & 4 & 50 & $<1$ & $<1$ & 10 & $<1$ & 3 & 1 & & 25 & $<1$ & 2 & 5 \\
\hline C14 & $<1$ & 35 & 50 & $<1$ & 4 & $<1$ & & 4 & 1 & & & & 1 & 5 \\
\hline C16b & $<1$ & 5 & 30 & $<1$ & $<1$ & 40 & $<1$ & 5 & $<1$ & & 15 & $<1$ & $<1$ & 5 \\
\hline $\mathrm{C} 25$ & $<1$ & 15 & 60 & $<1$ & & 10 & $<1$ & 5 & $<1$ & $<1$ & 5 & $<1$ & $<1$ & 5 \\
\hline $\mathrm{C} 26$ & $<1$ & 5 & 50 & $<1$ & & 20 & $<1$ & 3 & 1 & & 15 & $<1$ & 1 & 5 \\
\hline $\mathrm{C} 27$ & $<1$ & 5 & 50 & $<1$ & $<1$ & 10 & $<1$ & 10 & 1 & $<1$ & 20 & 1 & 1 & 2 \\
\hline
\end{tabular}

S 8

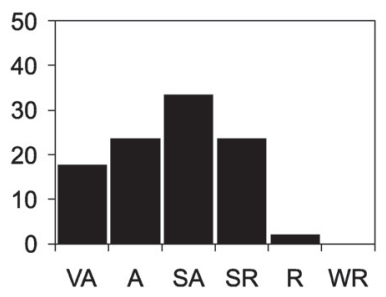

S 14

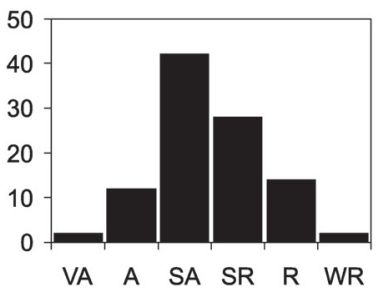

S 17

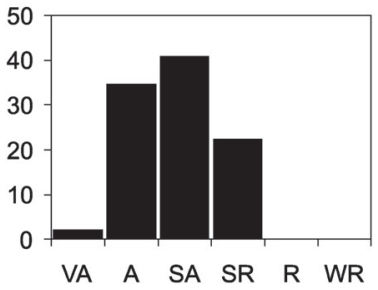

S 10

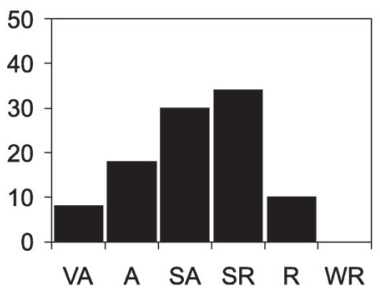

S 15

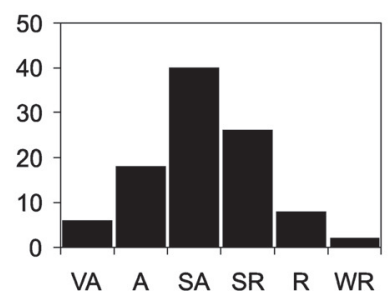

S 18

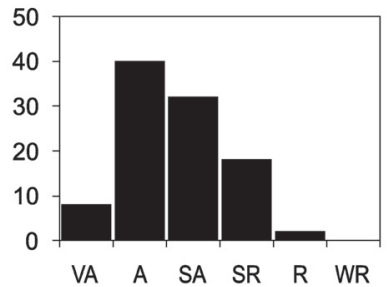

S12

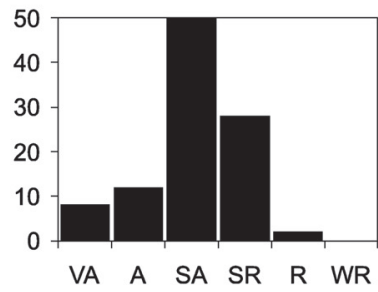

S 16

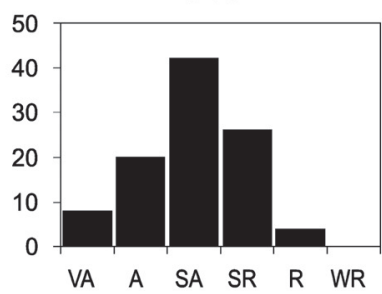

Fig. 8 - Histograms showing quartz gravel clasts roundness of the samples from the core S. VA - very angular, A - angular, SA - subangular, SR - subrounded, R - rounded, WR - well rounded. 

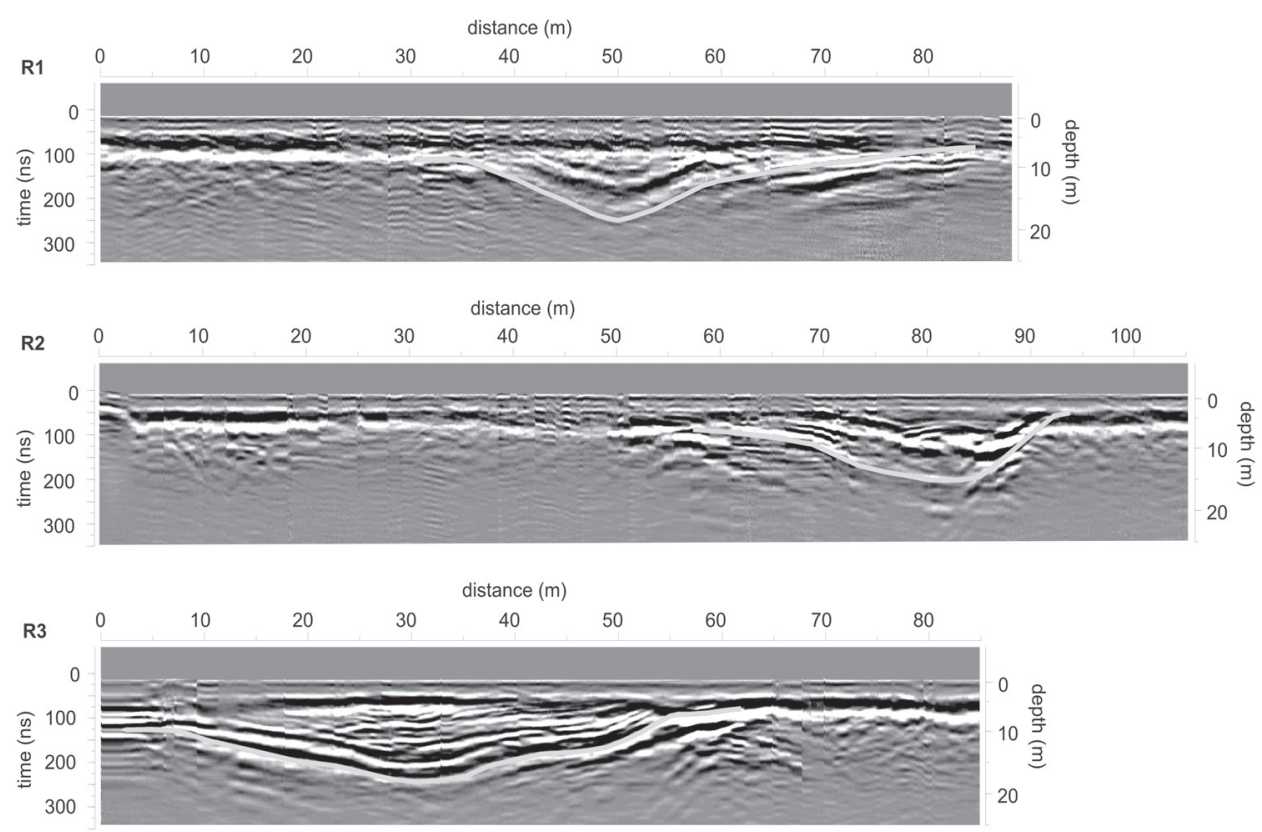

Fig. 9 - The GPR profiles R1, R2 and R3 across the channel with its floor indicated in white. See Fig. 2 for profiles locations.

Shares of individual heavy minerals are different for samples from cores B and C (Tab. 3). Material in core B drilled outside the channel is typified by predominance of rutile and tourmaline, with only five heavy minerals being detected. The small number of mineral types indicates that these sediments are colluvial loams deposited from the material of the adjoining slopes and that they contain heavy minerals originating from the local bedrock only. On the other hand, the heavy mineral composition of the material from core $\mathrm{C}$ reflects a very broad spectrum of heavy minerals.

\subsection{Bedrock morphology}

The results of GPR profiling indicate a buried channel located in the lowermost part of the col, as is indicated by the dashed lines in Figure 2. Three of the measured GPR profiles are shown on Figure 9. The channel length detected by the GPR method is $~ 550 \mathrm{~m}$. At both ends the channel gradually fades out. GPR measurements indicate that the channel width varies between 20 and $70 \mathrm{~m}$ (Fig. 2). The deepest channel thalweg is $\sim 12-18 \mathrm{~m}$ below the ground surface, but the depth of the channel itself is about $9-11 \mathrm{~m}$. Five profile lines measured by shallow seismic refraction are shown on Figure 2 . The results differ slightly from GPR measurements in terms of the width and depth of the channel. The seismic results (Fig. 10) indicate that the width of the channel varies between 55 and $100 \mathrm{~m}$ (Fig. 2) and its floor is $14-19 \mathrm{~m}$ below the ground surface. Solid bedrock was detected at depths of 5-8 $\mathrm{m}$ outside the channel. 

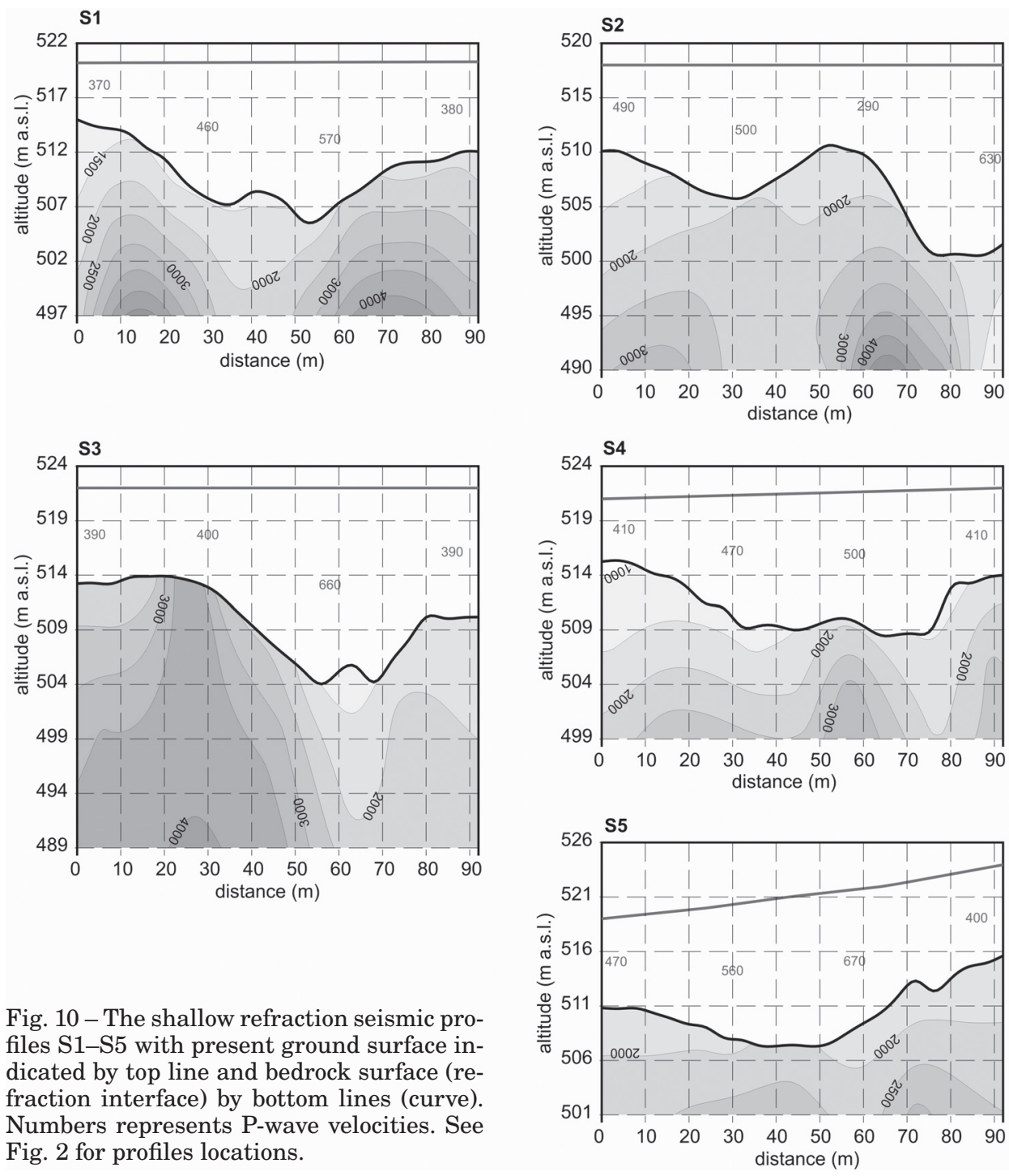

Fig. 10 - The shallow refraction seismic profiles S1-S5 with present ground surface indicated by top line and bedrock surface (refraction interface) by bottom lines (curve). Numbers represents P-wave velocities. See Fig. 2 for profiles locations.

According to both geophysical methods used, the channel cross-sections are variable in shape (Fig. 9, 10). The channel has some wider parts and some branches with variable depths. High seismic P-wave velocities indicate that the material under the refraction interface representing the channel floor is composed of solid bedrock. The channel floor is uneven and undulating according to both geophysical measurements, as shown on Figure 11. Both methods show a similar shape for the channel floor, with depth differences of $2-5 \mathrm{~m}$. This difference is caused by several factors. The GPR method is inaccurate in measuring absolute depth. Moreover, in some GPR profiles, interpretation of the channel floor is difficult due to many reflections displayed. The shallow refraction seismic was measured in five cross-sections, which does not allow 


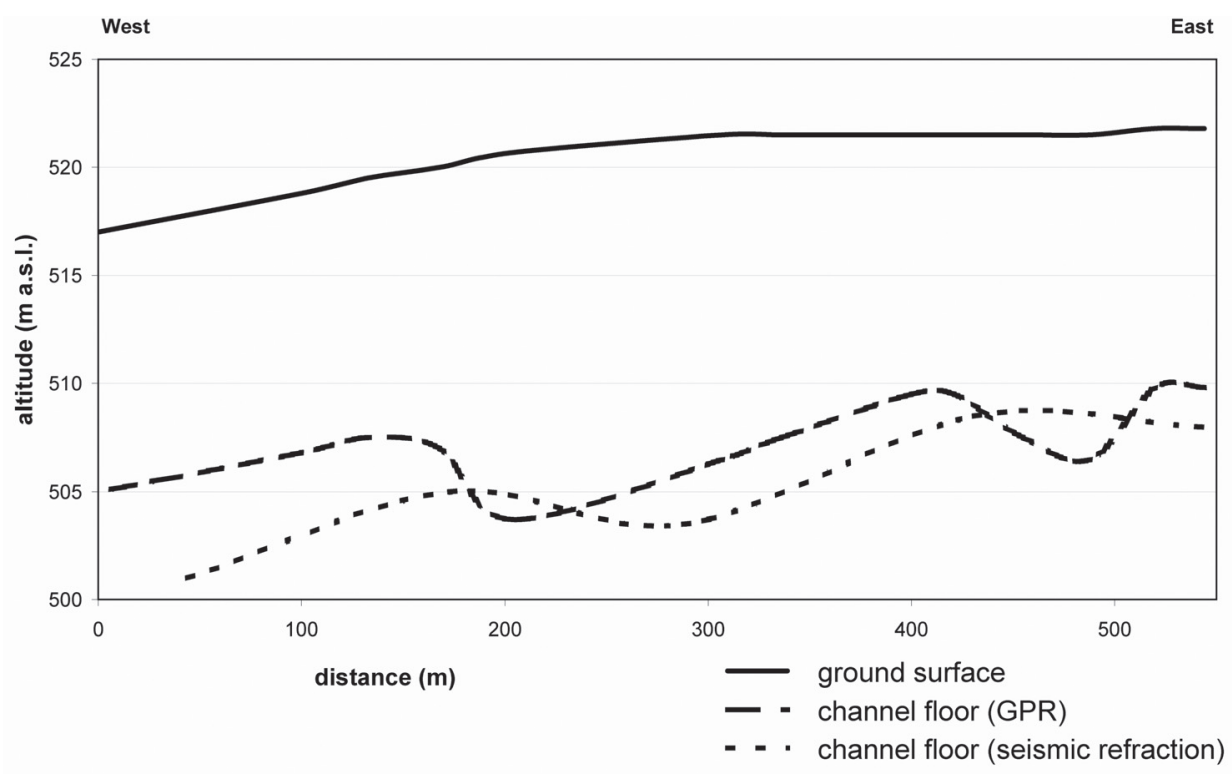

Fig. 11 - Longitudinal profile of the channel thalweg reconstructed by both geophysical methods. See Fig. 2 for the channel thalweg location.

showing the detailed shape of the channel floor in longitudinal profile. Although the exact shape of the channel floor in longitudinal profile remains unknown, it definitely descends from east to west with a general dip of $0.5-0.8^{\circ}$, as was shown congruently by both geophysical methods (Fig. 11).

\section{Interpretation and discussion}

The sedimentary character, especially bedding, sets of inversely graded units and sharp erosional boundaries and the presence of material, which travelled long distances, indicate high-magnitude glaciofluvial deposition of the material filling lower part of the channel (Fig. 3). It was shown by Maizels (1993), that thick inversely grading units (such as those found in the lower part of the core S) are deposited during a high-magnitude glacial floods being related to increasing flow competence on the rising limb of a flood hydrographs. This commonly occurs during the filling of subglacial channel (Marren 2005). Therefore we interpret the lower part of the channel infill up to the depth of $\sim 6 \mathrm{~m}$ in the core $\mathrm{S}$ as being deposited in the subglacial environment. The upper part of the glaciofluvial infill is composed by mostly sandy to muddy units, mostly also inversely graded, partly laminated (Fig. 3). However, these sets are usually $<1 \mathrm{~m}$ thick and represent a different flow regime. They might originate by the downstream accretion on longitudinal bars during lower flow velocities, but with high amount of available sandy to pebble material for the transport originating from the decaying ice sheet (Bluck 1974). However, common muddy units in the proglacial glaciofluvial environment might also indicate the reworking of basal subglacial facies by proglacial flows with numerous kettle lakes in front 
of the retreating ice sheet. The proglacial flow was surely much more limited comparing to the subglacial channel flow. The ice sheet decay in the Anděl Col area was rather slow leaving ice-cored moraine and producing kettle lakes during its decay. Both environments are quite typical for proglacial setting. However, it also indicates that most of the thawing water even during the slow ice sheet decay in this area must have been drained back below the ice sheet, as no subaerial terminoglacial fan (Zieliński, van Loon 2000), such as that at the Javorná site (Hanáček 2011), has been found here. It is evident that the minimum thickness of glaciofluvial sediments is $13 \mathrm{~m}$, the lower $\sim 9 \mathrm{~m}$ were deposited in subglacial environment, the upper $3 \mathrm{~m}$ then in front of the retreating ice sheet front.

Glaciofluvial units are covered with massive colluvial sand to gravel (1-3 m thick), for which the absence of lamination or bedding as well as worse sorting (comparing to the glaciofluvial material) and admixture of finer material are typical. They occur throughout the whole core B drilled outside the channel. The admixed finer fractions in massive colluvial sand originated from (chemical) weathering processes producing silty to clayey fractions, which decrease sorting of the material.

The low shares of clasts transported over a long distance is typical for sites, where glaciofluvial sedimentation is strongly controlled by local topography (Nývlt, Hoare 2000, 2011). Far travelled rocks are mostly transported in the ice sheet body in englacial and partly subglacial zone and these ice facies can hardly reach the elevated col area. The upper ice facies, which might reach the col area, are on the other hand rich in passively transported local angular supraglacial material. This was found to be true for similar localities in the glaciated region of Northern Bohemia (e.g. Nývlt, Hoare 2000, 2011; Nývlt 2008).

A broad spectrum of heavy minerals identified in the channel infill is typical for glacial sediments of multi-source origin (e.g. Sikorová et al. 2006). The major components are illmenite and muscovite, with chlorite and limonite in some samples being dominant as well. Muscovite and chlorite originated from schist or from gneisses and metagranitoids (Domečka 1970). However, there are also clear distant heavy minerals, such as magnetite, pyroxene, ilmenite or kyanite. They could not originate from surrounding bedrock (cf. Domečka 1970) and must have been transported to this area by an ice sheet. Kyanite may originate from near metasediments. Pyroxene is not present in local metagranitoids/orthogneisses, but is a common mineral in Quaternary sediments of the wider area (e.g. Czerwonka, Krzyszkowski 1994; Czerwonka 2004; Sikorová et al. 2006).

The other phenomenon is a vertical trend of individual provenance groups in the core S (Fig. 6). There is a visible trend toward reduced shares of local clasts between basal parts of the channel infill and the sediments at the depth $\sim 11 \mathrm{~m}$, which is connected with an increase in the proportions of quartz, near and Nordic rocks in the same interval. It is therefore possible that a part of quartz clasts was transported via an ice sheet to the col area, as is the case for near and Nordic rocks. Similar trend is visible in the change of clast shape and roundness, not only in ternary diagrams of the clast shapes (Fig. 7), where shares of more blocky clasts increases and histograms of the clast roundness (Fig. 8), where higher amounts of subrounded to rounded clasts are present. But this trend is best visible in the covariant plot of $\mathrm{C}_{40}$ and RA values (Fig. 12). 


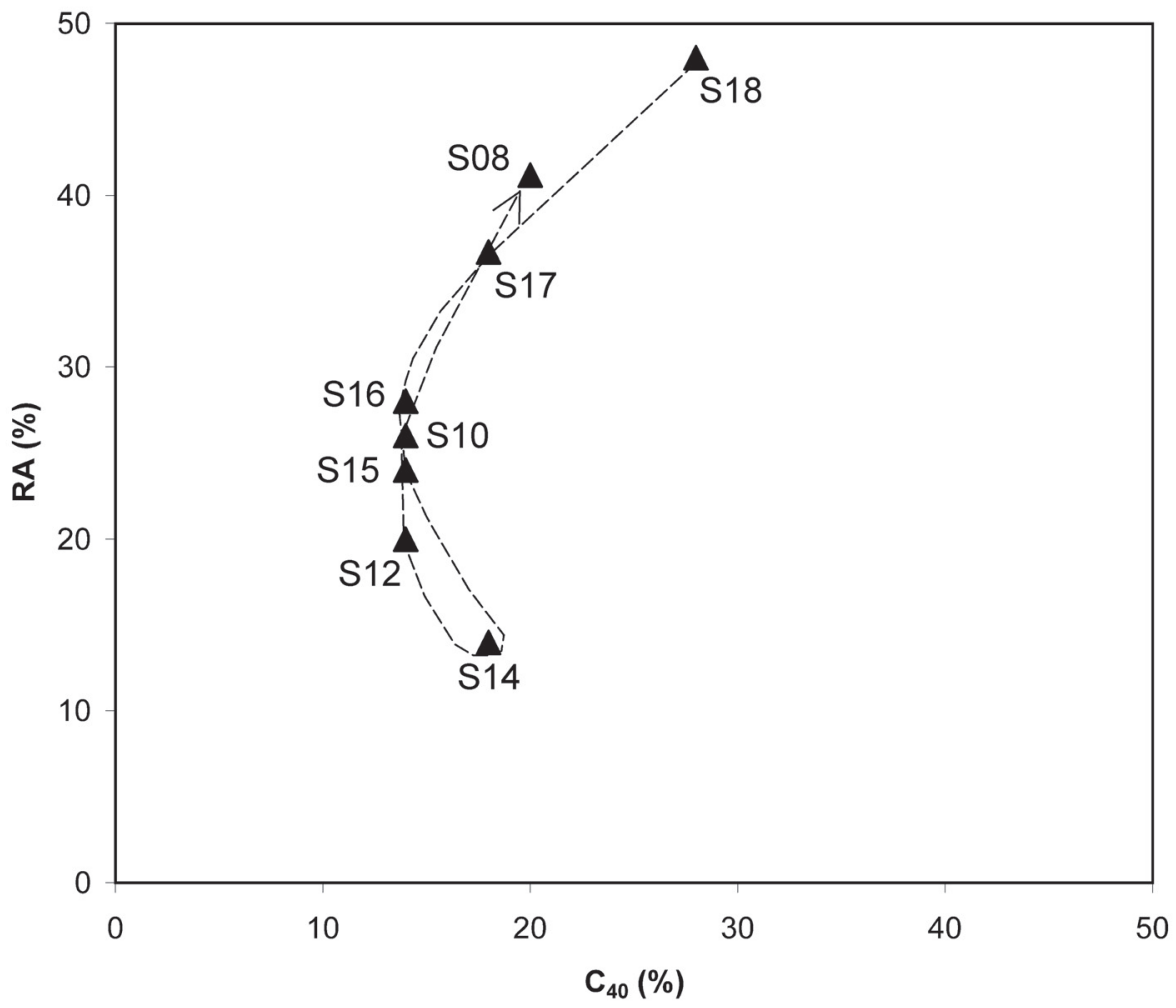

Fig. 12 - Co-variant plot of $\mathrm{C}_{40}$ and RA values for the quartz gravel clasts of the samples from the core $\mathrm{S}$.

An opposite trend may be seen between depths of 11 and $7 \mathrm{~m}$, where the next coarsening upward set is present (Fig. 3). There is evident increase in local material and decrease in distal material. The share of quartz clasts is similar to the share of near and Nordic clasts. This is accompanied by the increase of the proportion of angular and less spherical clasts; as it is seen on Figure 12. These changes are typical for different fluxes of released meltwaters originating from the ice sheet. At the depth of $\sim 11 \mathrm{~m}$ highest amount of better-rounded and far-travelled clasts is released from the ice sheet. From this standpoint, we may also interpret the succession a depth of $\sim 11 \mathrm{~m}$ as being deposited at the beginning of the ice decay (i.e., just after the maximum extent of the ice sheet in the col area), when highest amount of ice-transported material is released. The simplified reconstruction is shown on Figure 13. The next coarsening upward set does not bring more distal material and is typified by the predominance of the local material originating mostly from supraglacial ice facies and represent thus the retreat of the ice sheet margin from this area.

The size and shape of the channel differ in both geophysical surveying methods employed, i.e., in shallow seismic refraction and GPR measurements. The seismic refraction method is regarded as being more reliable and accurate for measuring the channel depth, as the bedrock is characterized by a refraction interface with substantial contrast in P-wave velocities. On the other hand, 

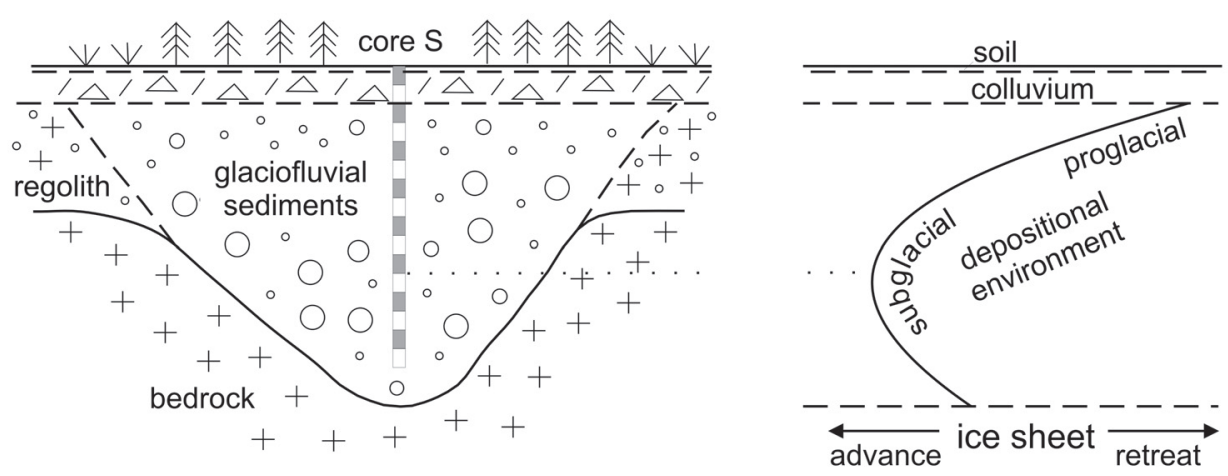

Fig. 13 - Sketch section of the channel in the left with the interpretation of ice sheet advance and retreats, together with depositional environments for individual parts of the channel infill in the right. Vertical line with $1 \mathrm{~m}$ banding in the centre of the channel represents the position of the core S.

GPR data show more reflections, which represent boundaries between layers of different grain-size, as well as the boundary between sediments and bedrock. The seismic refraction method is also more precise in mapping the channel width. In GPR record synclines appear narrower and anticlines broader than in reality (Stewart et al. 2006); therefore the real channel width is probably larger than our GPR data show. The floor of the channel is undulating; this fact was detected by both geophysical methods, and the channel is eroded in solid bedrock.

An important finding is that the channel floor slopes from east to west, as was proved congruently by both geophysical methods (Fig. 11). This indicates water flow from the east to the west. The channel is situated in the lowermost section of the col. In the east the channel continues transversely across the northern slope, whereas south of it a recent dry (intermittent) channel is located. This indicates the col was wider during preglacial times than it is in present. The valley head east of the col was situated $>200 \mathrm{~m}$ further to the east and reached its recent position by backward erosion after the ice sheet's retreat. This implies, that the postglacial backward erosion might have changed the channel length and width at its eastern side. The geometry of the channel might imply both its subglacial or proglacial origin, however as it was shown by sedimentary characteristics of channel infill its subglacial origin is more likely.

Shallow refraction seismic results indicate that there is solid bedrock next to the channel at a depth of 5-8 $\mathrm{m}$. This indicates that the channel was partly eroded in the weathered regolith, but its lower part (10-12 m) was eroded in the solid bedrock, as shown on Figure 13. However, the incision of $>10 \mathrm{~m}$ into a solid bedrock is hardly conceivable in the proglacial environment on such an exposed site as is the col. Therefore, we interpret this channel as a Nye channel (Nye 1973) incised into the bedrock. If the ice sheet front just reached the edge of the col, its meltwaters would be draining back under the ice sheet through fissures in the ice and such a channel would not originate. Therefore the subglacial origin of this channel is more feasible, as it is supported both by sedimentological and geophysical results. It is hard to reconstruct the advance direction of the ice sheet front into the col area, as there are no adequate 
sediments preserved in the vicinity of the col. However, as the subglacial flow was from the east to the west, which is best visible for the upper part of the glaciofluvial succession, it is probable that the flow was consistent with the advance direction of the ice. Therefore, it seems, that the ice sheet outlet entered or crossed the col from the east and its meltwaters drained partly subglacially to the proglacial zone located to the west (in the Czech territory).

We failed to detect subglacial tills in the col area, which is not unusual due to the limited thickness of the ice present and subsequent removal of superficial sediments. The same was true for the Oldřichov Col (Nývlt 2003), where no glacigennic sediments are present and its crossing by an ice sheet outlet was proved by the presence of glaciofluvial deposits in the valley south of the col (Králík 1989, Nývlt 2003). Therefore it is hard to reconstruct the maximum advance of the ice sheet over the Anděl Col. It is obvious that the ice sheet's surface was higher than the col $(522 \mathrm{~m})$ and the minimum thickness of the ice here was few tens of metres. We suggest that the altitude limit of the ice sheet during its maximum advance was $\sim 540 \mathrm{~m}$.

\section{Conclusions}

The presented results bring new consequences for palaeogeographical reconstruction of the maximum Middle Pleistocene ice sheet extent in the Jizera Mts. The ice sheet front advanced to the Anděl Col from the east, filled the valley of the Granicznik River and crossed the col. In the subglacial environment a deeply incised Nye channel was eroded by subglacial flow. Geophysical methods showed that the channel is eroded in the bedrock and weathered regolith, which evolved in the lowermost part of the col. The channel is $>550 \mathrm{~m}$ long and 55-100 m wide. Its floor lies about 14-19 m below the present surface and its floor descends from east to west indicating the water flow in this direction.

The channel is filled by $>13 \mathrm{~m}$ of glaciofluvial sand, gravel and mud, which is covered by $1-2 \mathrm{~m}$ thick colluvial deposits. The lower $\sim 9 \mathrm{~m}$ of the sedimentary succession filling the channel was deposited during high-magnitude glacial floods in the subglacial channel. Individual coarsening upward sets represent events of higher release of far-travelled better-rounded material from the ice sheet. The last subglacial coarsening upward set reflects the ice sheet front decay bringing more local material originating mostly from supraglacial ice facies into the channel. The upper $3 \mathrm{~m}$ of the glaciofluvial sediments were deposited partly by the downstream accretion in form of longitudinal bars in the proglacial position and by the reworking of sublacial till facies with numerous kettle lakes evolving in the proglacial position, i.e. close to the ice sheet front. However, both indicates a very slow ice decay in the Anděl Col area and the predominant drainage of meltwaters back below the retreating ice sheet front.

No subglacial tills have been found in the col area, which is not unusual for such an exposed site. Although the exact position of the ice sheet near the col remains unknown, the ice sheet surface was surely higher than the col $(522 \mathrm{~m})$. These results show that the maximum vertical extent of the ice sheet on both sides of the col was higher than has been considered recently. The precise maximum extent of the ice sheet in the wider area around the col is hard to assess as most of the glacial sediments and landforms were removed, destroyed 
or modified after deglaciation. However, we suggest that the maximum vertical extent of the ice sheet in the Anděl Col was at $540 \mathrm{~m}$ and the ice in the col was few tens of metres thick. The Anděl Col is the highest area in Northern Bohemia covered by the ice sheet and changes our knowledge about the maximum vertical extent of Middle Pleistocene ice sheet extent in Western Sudetes.

Acknowledgements: We would like to thank Václav Tíma to draw our attention to this area by presenting us photographs of Nordic rocks from the Anděl Col. Constructive comments on earlier drafts of the manuscript provided by Peter G. Hoare, Tomasz Zieliński and Martin Hanáček are highly acknowledged. We are very grateful for the constructive comments of Piotr Migon and an anonymous journal reviewer, which substantially helped to clarify the final version of this paper.

\section{References:}

BADURA, J., PRZYBYLSKI, B. (1998): Extent of the Pleistocene ice sheets and deglaciation between the Sudeten and the Silesian Rampart. Biuletyn Państwowego Instytutu Geologicznego, 385, pp. 9-28.

BENN, D.I., BALLANTYNE, C.K. (1994): Reconstructing the transport history of glacigenic sediments: a new approach based on the co-variance of clast form indices. Sedimentary Geology, 91, pp. 215-227.

BERG, G., AHRENS, W. (1925): Geologische Karte von Preussen und benachbarten deutschem Ländern 1:25000, Friedeberg am Queiss, Berlin.

BERGER, H.J., ZITZMANN, A., OPLETAL, M., NÝVLT, D., VALEČKA, J., PROUZA, V., BADURA, J., PRZYBYLSKI, B. (2002): Geologische Übersichtskarte 1:200 000, CC 5550 Görlitz. BGR Hannover.

BLUCK, B.J. (1974): Structure and directional properties of some valley sandur in southern Iceland. Sedimentology, 21, pp. 533-554.

ČERNÁ, B. (2011): Reconstruction of the continental glaciation in the northern slope of the Jizera Mts. Journal of Geological Sciences, Anthropozoic, 27, pp. 23-38.

CHALOUPSKÝ, J., ed. (1990): Geologická mapa ČR, list 03-12 03-11 Frýdlant. ÚÚG Praha.

CZERWONKA, J.A. (2004): Silesian and Great Poland glacial till lithostratigraphical provinces. Przeglad Geologiczny, 52, pp. 421-429.

CZERWONKA, J.A., KRZYSZKOWSKI, D. (1994): Pleistocene stratigraphy and till petrography of the Central Great Poland Lowland, Western Poland. Folia Quaternaria, 65, pp. 7-71.

DOMEČKA, K. (1970): Předvariské granitoidy Západních Sudet. Sborník geologických věd, Geologie, 18, pp. 161-191.

FOLK, R.L. (1954): The distinction between grain size and mineral composition in sedimentary-rock nomenclature. Journal of Geology, 62, pp. 344-359.

FOLK, R.L., WARD, W.C. (1957): Brazos River bar: a study in the significance of grain size parameters. Journal of Sedimentary Petrology, 27, pp. 3-26.

GÁBA, Z. (1972): Nejzazší výskyty uloženin kontinentálního zalednění na Jesenicku. Časopis Slezského Muzea, Opava (A), 21, pp. 135-139.

GALE, S.J., HOARE, P.G. (1991): Quaternary sediments: petrographic methods for the study of unlithified rocks. Belhaven. London, $323 \mathrm{pp}$.

GRAHAM, D.J., MIDGLEY, N.G. (2000): Graphical representation of particle shape using triangular diagrams: An Excel spreadsheet method. Earth Surface Processes and Landforms, 25, pp. 1473-1477.

HANÁČEK, M. (2011): Sedimenty terminoglaciálního kuželu v údolí Javorné na Zlatohorsku. Acta Musei Moraviae, Sci. geol., 96, pp. 61-86.

HEAD, K.H. (1984): Manual of laboratory testing. Volume 1: Soil Classification and Compaction Tests. ELE International Ltd, London, 339 pp. 
JAHN, A. (1960): Czwartorzęd Sudetów. In: Teisseyre, H. (ed.): Regionalna Geologia Polski, tom III, Sudety, 2, Polske Towarziszstwo Geologiczne, Kraków, pp. 358-418.

KORNAŚ, J., (1957): Szczegółowa Mapa Geologiczna Sudetów 1:25 000, ark. Pobiedna, Inst. Geol., Warszawa.

KOZDRÓJ, W. KRENTZ, O., OPLETAL, M. eds. (2001): Comments on the Geological Map Lausitz-Jizera-Karkonosze (without Cenozoic sediments) 1:100,000. Polish Geological Institute, Warszawa, $64 \mathrm{pp}$.

KRÁLÍK, F. (1989): Nové poznatky o kontinentálních zaledněních severních Čech. Journal of Geological Sciences, Anthropozoic, 19, pp. 9-74.

KRZYSZKOWSKI, D., MIGOŃ, M., SROKA, W. (1995): Neotectonic Quaternary history of the Sudetic Marginal Fault, SW Poland. Folia Quaternaria, 66, pp. 73-98.

MAIZELS, J. (1993): Lithofacies variations within sandur deposits: the role of runoff regime, flow dynamics and sediment supply characteristics. Sedimentary Geology, 85, pp. 299-325.

MARREN, P.M. (2005): Magnitude and frequency in proglacial rivers: a geomorphological and sedimentological perspective. Earth-Science Reviews, 70, pp. 203-251.

NYE, J.F. (1973): Water at the bed of a glacier. Int. Assoc. Sci. Hydrol., Publication, 95, pp. 189-194.

NYYVT, D. (1998): Kontinentální zalednění severních Čech. Geografie, 103, pp. 445-457.

NÝVLT, D. (2003): Geomorphological aspects of glaciation in the Oldřichov Highland, Northern Bohemia, Czechia. AUC-Geographica, 35, Suppl., pp. 171-183.

NÝVLT, D. (2008): Paleogeografická rekonstrukce kontinentálního zalednění Šluknovské pahorkatiny. Ph.D. thesis, Charles University, Praha, 103 pp.

NÝVLT, D., ENGEL, Z., TYRÁČEK, J. (2011): Pleistocene Glaciations of Czechia. In: Ehlers, J., Gibbard, P.L., Hughes, P.D. (eds): Quaternary Glaciations - Extent and Chronology, A closer look. Developments in Quaternary Science, 15, Elsevier, pp. 37-46.

NÝVLT, D., HOARE, P.G. (2000): Valounové analýzy glacifluviálních sedimentů severních Čech. Bulletin of the Czech Geological Survey, 75, pp. 121-126.

NÝVLT, D., HOARE, P.G. (2011): Petrology, provenance and shape of clasts in the glacifluvial sediments of the Mníšek member, northern Bohemia, Czechia. Journal of Geological Sciences, Anthropozoic, 27, pp. 5-22.

POWERS, M. (1953): A new roundness scale for sedimentary particles. Journal of Sedimentary Petrology, 23, pp. 117-119.

RŨŽIČKA, M. (2004): The pleistocene glaciation of Czechia. In: Ehlers, J., Gibbard, P.L. (eds): Quaternary Glaciations - Extent and Chronology. Developments in Quaternary Science, 15, Elsevier, Amsterdam, pp. 27-34.

SEKYRA, J. (1961): Traces of the Continental Glacier on the territory of Northern Bohemia. Zesz. nauk. Uniw. Wroclawskiego, B, 8, pp. 71-79.

ŠIBRAVA, V. (1967): Study of the Pleistocene of the glaciated and non-glaciated area of the Bohemian Massif. Journal of Geological Sciences, Anthropozoic, 4, pp. 7-38.

SIKOROVÁ, J., VÍŠEK, J., NÝVLT, D. (2006): Texture and petrography of glacial deposits in the northern foothill of the Hrubý Jeseník and Rychlebské Mts., Czechia. Geological Quarterly, 50, pp. 345-352.

SNEED, E.D., FOLK, R.L. (1958): Pebbles in the lower Colorado River, Texas - a study in particle morphogenesis. Journal of Geology, 66, pp. 114-150.

STEWART, A. GREENHALGH, S.A., MARESCOT, L. (2006): Modeling and Migration of 2-D Georadar Data: A Stationary Phase Approach. IEEE Transactions on Geoscience and Remote Sensing, 44, pp. 2421-2429.

SZPONAR, A. (1986): Chronostratygrafia I etapy deglacjacji strefy przedgórskiej Sudetów w okresie zlodowacenia środkowopolskiego. Acta Universitatis Wratislaviensis No. 963, Studia Geograficzne XLV, Wroclaw, 202 pp.

TRACZYK, A. (2004): Wplyw rzeźby na przebieg transgresji lądolodu skandynawskiego w Kotlinie Kamiennogórskiej w Sudetach Środkowych. Prace Inst. Geogr. Akademii Świętokrzyskiej w Kielcach, 13, pp. 151-168.

WALCZAK, W. (1968): Sudety. PWN, Warszawa, 384 pp.

ZIELIŃSKI, T., VAN LOON, A.J. (2000): Subaerial terminoglacial fans III: overview of sedimentary characteristics and depositional models. Geologie en Mijnbouw/Netherlands Journal of Geosciences, 79, pp. 93-107. 


\section{POHŘBENÉ GLACIFLUVIÁLNÍ KORYTO V SEDLE POD ANDĚLSKÝM VRCHEM V SEVERNÍCH ČECHÁCH: NOVÝ DOKLAD PRO ROZSAH STŘEDOPLEISTOCENNÍCH LEDOVCOVÝCH ŠTÍTŮ V ZÁPADNÍCH SUDETECH}

Tato studie přináší doklady nových nálezů glacifluviálních sedimentů vyplňujících pohřbené koryto v sedle pod Andělským vrchem (522 m n. m.) v Jizerských horách, poblíž česko-polských státních hranic. Minimálně $550 \mathrm{~m}$ dlouhé a 55-100 m široké koryto vyplněné glacifluviálními sedimenty bylo zjištěno pomocí geofyzikálních metod v nejnižší části sedla. Báze koryta se nachází 14-19 m pod současným povrchem, díky gradientu od východu k západu odvodňovalo koryto čelo ledovcového štítu v tomto směru. Koryto je zahloubené do pevného podloží a částečně zvětralin, a představuje tak Nye koryto. Koryto je vyplněno $>13 \mathrm{~m}$ glacifluviálních písků, štěrků a hlín, které jsou překryty 1-2 m mocnými svahovými sedimenty. Značná část glacifluviálních sedimentů byla uložena v subglaciálním prostředí během tání ledovcového štítu, kdy docházelo k uvolňování značného množství horninového materiálu z ledovce. Dokládají to vzhůru hrubnoucí sety písků a štěrků s vyšším podílem nordických hornin. Poslední z těchto setů s dominancí místního materiálu dokládá ústup čela ledovce a ukládání materiálu především z povrchových partií čela ledovcového štítu. Svrchní $3 \mathrm{~m}$ mocná vrstva glacifluviálních sedimentů byla uložena před pomalu tajícím čelem ledovcového štítu, částečně poproudovou akrecí v podobě podélných lavic a také redepozicí původně subglaciálního materiálu za vzniku depresí po mrtvém ledu, kde vznikala zahloubená jezírka pomalu vyplňovaná jemnozrnnými laminovanými sedimenty. V závěrečné fázi glacifluviální sedimentace odtékaly tavné ledovcové vody směrem $\mathrm{k}$ východu zpět $\mathrm{k}$ ustupujícímu čelu ledovcového štítu. $\mathrm{V}$ oblasti sedla nebyly nalezeny žádné subglaciální tilly, což není neobvyklé vzhledem k poloze lokality. Čelo ledovcového štítu v prostoru sedla pod Andělským vrchem bylo maximálně první desítky metrů mocné. Maximální výškový zásah ledovcového štítu v Andělském sedle lze vyčíslit hodnotou 540 m. Andělské sedlo je nejvyšším známým místem v severních Čechách, které bylo zasaženo ledovcovým štítem, a významně tak upřesňuje naše znalosti o maximálním výškovém zásahu středopleistocenních ledovcových štítů v Západních Sudetech.

Obr. 1 - Schematická geologická mapa okolí sedla pod Andělským vrchem s maximálními zásahy ledovcových štítů podle dřivějších autorů.

Obr. 2 - Topografická mapa sedla pod Andělským vrchem s lokalizací vrtů A, B, C a S, linií georadarových profilů R1, R2 a R3, profilů mělké refrakční seismiky S1, S2, S3, S4 a S5, rekonstruované údolnice a okraje paleokoryta podle obou použitých geofyzikálních metod.

Obr. 3 - Litologické profily jádry A, B, C a S včetně interpretací depozičního prostředí a zrnitostního složení vzorků. Lokalizace vrtů je znázorněna na obr. 2, zrnitostní parametry sedimentů jsou uvedeny $\mathrm{v}$ tabulce 1 . Jádro $\mathrm{S}$ je zobrazeno $\mathrm{v}$ jiném měřítku.

Obr. 4 - Diagramy průměru zrnitosti $\left(M_{z}\right)$ a koeficientu vytřídění $(\sigma)$ a průměru zrnitosti $\left(M_{z}\right)$ a šikmosti $\left(S k_{I}\right)$ pro glacifluviální a koluviální sedimenty z vrtných jader B, C a S.

Obr. 5 - Vertikální trendy provenienčních skupin ve štěrkových klastech glacifluviálních sedimentů z jader C, A a S. Vzorky označené hvězdičkou neobsahují dostatečné množství klastů pro statisticky objektivní porovnání.

Obr. 6 - Vertikální změny provenienčních skupin klastů frakce 4-8 mm z vrtného jádra S.

Obr. 7 - Diagramy tvarů štěrkových klastů ze vzorků z vrtného jádra $\mathrm{S}$ s hodnotou $\mathrm{C}_{40}$. Pro lokalizaci vzorků viz obrázek 6 a tabulku 1.

Obr. 8 - Histogramy skupin zaoblení křemenných klastů vzorků z vrtného jádra S. VA velmi ostrohranný, A - ostrohranný, SA - poloostrohranný, SR - polozaoblený, $\mathrm{R}$ - zaoblený, WR - dokonale zaoblený.

Obr. 9 - Glacifluviální koryto na georadarových profilech R1, R2 a R3 s bíle vyznačenou bází koryta. Lokalizace jednotlivých profilů je znázorněna na obr. 2.

Obr. 10 - Profily mělké refrakční seismiky S1-S5 s vyznačeným povrchem reliéfu podloží. Vyznačené číselné hodnoty odpovídají rychlostem šírení P-vln. Pro lokalizaci jednotlivých profilů viz obr. 2. 
Obr. 11 -Podélný profil údolnicí koryta rekonstruovaný na základě obou geofyzikálních metod. Pro průběh údolnice koryta viz obr. 2.

Obr. 12 -Diagram hodnot $\mathrm{C}_{40}$ a RA pro křemenné štěrkové klasty ze vzorků z vrtného jádra $\mathrm{S}$.

Obr. 13 -Schematický příčný řez korytem vlevo a interpretace postupu a ústupu ledovcového štítu a depozičního prostředí pro jednotlivé části výplně koryta vpravo. Svislá linie s metrovým páskováním ve středu koryta představuje pozici vrtného jádra $\mathrm{S}$.

Authors' affiliations: B. Černá and Z. Engel are affiliated with the Department of Physical Geography and Geoecology, Faculty of Science, Charles University in Prague, Albertov 6, 12843 Praha 2, Czechia. D. Nývlt is affiliated with the Czech Geological Survey, Brno branch, Leitnerova 22, 65869 Brno, Czechia, e-mail: daniel.nyvlt@geology.cz.

Initial submission, 29 September 2011; final acceptance 24 April 2012.

Please cite this article as:

ČERNÁ, B., NÝVLT, D., ENGEL, Z. (2012): A buried glaciofluvial channel in the Anděl Col, Northern Bohemia: new evidence for the Middle Pleistocene ice sheets extent in Western Sudetes. Geografie, 117, No. 2, pp. 127-151. 